The Black Creek-Peedee Formational Contact (Upper Cretaceous) in the Cape Fear River Region of North Carolina

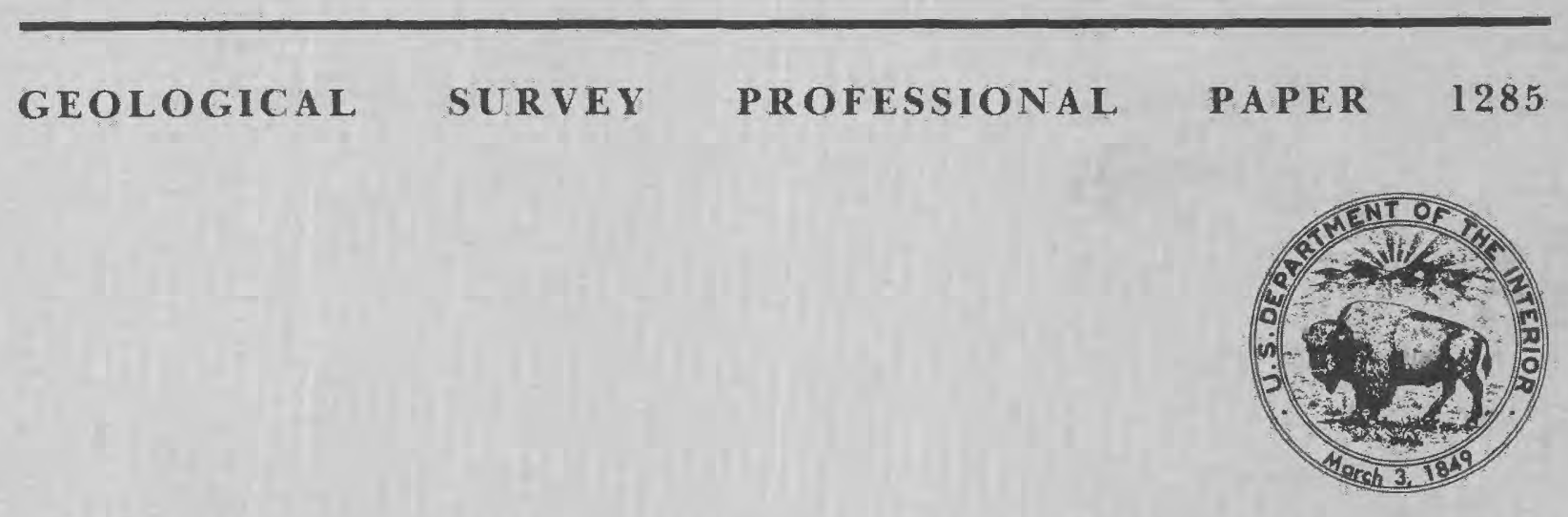





\section{The Black Creek-Peedee Formational Contact (Upper Cretaceous) in the Cape Fear River Region of North Carolina}

By NORMAN F. SOHL and RAYMOND A. CHRISTOPHER

GEOLOGICAL SURVEY PROFESSIONAL PAPER 1285

Stratigraphic and paleontologic data suggest a disconformable relationship between the Black Creek and Peedee Formations along the Cape Fear River of North Carolina

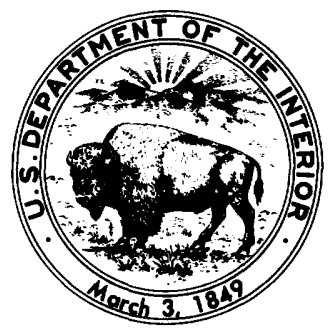




\section{UNITED STATES DEPARTMENT OF THE INTERIOR}

JAMES G. WATT, Secretary

GEOLOGICAL SURVEY

Dallas L. Peck, Director

Library of Congress Cataloging in Publication Data

Sohl, Norman F. (Norman Frederick), 1924-

The Black Creek-Peedee formational contact (Upper Cretaceous) in the Cape Fear River region of North Carolina.

(Geologiçal Survey profesšional paper; 1285)

Bibliography: $p$.

Supt. of Docs. no.: I 19.16:1285

1. Geology, Stratigraphic-Cretaceous. 2. Geology-North Carolina-Cape Fear River Watershed.

I. Christopher, Raymond A. II. Title. III. Series. 


\section{CONTENTS}

Abstract

Introduction

Geographic setting

Previous work.

Section descriptions

Walkers Bluff

Stratigraphic column, upstream section

Stratigraphic column, medial section

Stratigraphic column, downstream section

Paleontology

Discussion

Jessups Landing

Stratigraphic column

Paleontology

Discussion

Deepwater Point

Lithologic descriptions of the samples

Paleontology

Donoho Creek Landing.

Stratigraphic column

Paleontology

Discussion

\begin{tabular}{|c|c|c|}
\hline Page & Section descriptions-Continued & Page \\
\hline 1 & Robinsons Landing .................. & 20 \\
\hline 1 & Stratigraphic column & 20 \\
\hline 2 & Paleontology ....................... & 20 \\
\hline 2 & 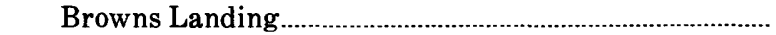 & 20 \\
\hline 6 & Stratigraphic column & 20 \\
\hline 6 & Paleontology ............................. & 20 \\
\hline 12 & Discussion .......................... & 20 \\
\hline 12 & Remarks & 20 \\
\hline 12 & Interpretations & 20 \\
\hline 12 & 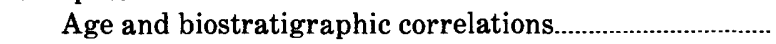 & 20 \\
\hline 12 & Paleoenvironmental interpretations & 26 \\
\hline 17 & 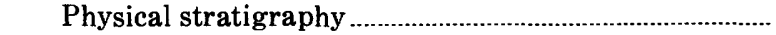 & 28 \\
\hline 17 & Conclusions ……………………………………… & 30 \\
\hline 17 & Measured sections & 31 \\
\hline 17 & Walkers Bluff, upstream section & 31 \\
\hline 17 & 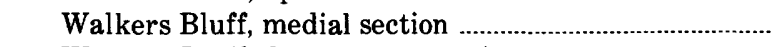 & 33 \\
\hline 17 & Walkers Bluff, downstream section & 34 \\
\hline 17 & Jessups Landing & 35 \\
\hline 17 & Donoho Creek Landing & 35 \\
\hline 17 & Robinsons Landing & 36 \\
\hline 17 & Browns Landing & 36 \\
\hline 19 & 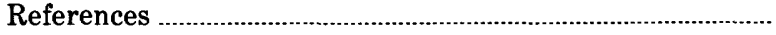 & 37 \\
\hline
\end{tabular}

\section{ILLUSTRATIONS}

Figure 1. Map of the Cape Fear River, N.C., between Walkers Bluff and Browns Landing, showing localities discussed

2-4. Stratigraphic columns of:

2. Upstream section at Walkers Bluff

3. Medial section at Walkers Bluff

4. Downstream section at Walkers Bluff

5. Diagram showing physical correlation of the lithologic units exposed at the downstream, medial, and upstream sections at Walkers Bluff

6-9. Stratigraphic columns of:

6. Jessups Landing

7. Donoho Creek Landing

8. Robinsons Landing

9. Browns Landing

10. Chart showing stratigraphic ranges of 11 biostratigraphically important invertebrate fossils that are found in exposures along the Cape Fear River between Walkers Bluff and Browns Landing

11. Chart showing stratigraphic ranges of $\mathbf{3 1}$ biostratigraphically important pollen species that are found in exposures along the Cape Fear River between Walkers Bluff and Browns Landing.

12. Biostratigraphic correlation chart of the outcropping Cretaceous sections between Walkers Bluff and Browns Landing. Cape Fear River, N.C., and the sections of New Jersey and the Chattahoochee River, Ala. and Ga.....

13. Diagram showing the relative frequency of occurrence (in percent) of dinoflagellates and acritarchs in palynologic samples from Walkers Bluff, Jessups Landing, Deepwater Point, Donoho Creek Landing, Robinsons Landing, and Browns Landing, Cape Fear River, N.C.

14. Schematic cross section along part of the Cape Fear River showing physical, paleoenvironmental, and biostratigraphic interpretations of the relationship between the Black Creek and Peedee Formations

\section{TABLES}

TABLE 1. Location of the Cape Fear River sections discussed in this report

2. Distribution of megainvertebrate fossils and vertebrate remains in the outcropping Cretaceous sections along the Cape Fear River, N.C., between Walkers Bluff and Browns Landing

3. Distribution of biostratigraphically important pollen species in the outcropping Cretaceous sections along the Cape Fear River, N.C., between Walkers Bluff and Browns Landing

Page 



\title{
THE BLACK CREEK-PEEDEE FORMATIONAL CONTACT (UPPER CRETACEOUS) IN THE CAPE FEAR RIVER REGION OF NORTH CAROLINA
}

\author{
By NORMAN F. SOHL and RAYMOND A. CHRISTOPHER ${ }^{1}$
}

\begin{abstract}
Stratigraphic and paleontologic data from six sections exposed along the Cape Fear River, N.C., suggest that the contact between the Upper Cretaceous Black Creek and overlying Peedee Formations is unconformable. The unconformity is exposed in three closely spaced sections between mileposts 49.5 and 50.25 and is indicated by the presence of a thin (2-inch-thick) zone at the base of the Peedee Formation that contains worn and abraded bone and shell, bored phosphate pebbles, teeth, and clasts reworked from the underlying Black Creek Formation in a matrix of poorly sorted coarse-grained sand. The disconformity represents a relatively short hiatus that occurred sometime between the latest Campanian and earliest Maestrichtian (that is, during the time of concurrence of Exogyra ponderosa erraticostata and $E$. costata). The short duration of the hiatus makes it difficult to detect by means of existing megafossil and (or) palynologic zonations. However, lithologic and paleontologic evidence suggests that a major paleoenvironmental change takes place at the disconformity. Below the disconformity, the upper part of the Black Creek Formation consists of a series of interfingering and discontinuous lithologic units that reflect rapidly changing nearshore environments. Above the disconformity, the basal part of the Peedee Formation consists of massive, glauconitic, bioturbated, muddy sands of open marine shelfal origin.

Previous interpretations of the ages of the Black Creek and Peedee Formations and the nature of their contact were based, in large part, on an interpretation of the fauna contained in and the stratigraphic position of a zone of sandstone blocks of Cretaceous age that had not been recognized previously as having been reworked into the basal part of the Waccamaw Formation of early Pleistocene age. These blocks occur in an outcrop referred to as Walkers Bluff, located 10 river miles upstream from the exposed Black Creek-Peedee contact.
\end{abstract}

\section{INTRODUCTION}

According to Stephenson (1923), the Cretaceous System of the Carolina Coastal Plain is best exposed along the Cape Fear River of North Carolina. Here, the Upper Cretaceous Series consists of three formations; in ascending stratigraphic order, they are the Cape Fear, Black Creek, and Peedee Formations. The excellence and accessibility of the exposures along the river have prompted many workers to use the Cape Fear River section as the basis for interpreting the stratigraphic relationships among these formations in other areas (for example, Stephenson, 1912, 1923; Brett and Wheeler, 1961; Heron and Wheeler, 1964; Swift, 1964; Swift and Heron, 1967, 1969; Swift and others, 1969; Christopher and others, 1979). Stratigraphic relationships among the Upper Cretaceous units and with the underlying and overlying rocks are well established for most of the section; unconformities are recognized (1) at the base of the Cape Fear Formation, where the Cape Fear rests nonconformably on crystalline rocks of the Piedmont province, (2) between the Cape Fear and Black Creek Formations, and (3) at the top of the Peedee Formation, where post-Cretaceous rocks disconformably overlie the Peedee. However, the nature of the contact between the Black Creek and Peedee Formations is still unresolved; it has been regarded as gradational by some workers (for example, Stephenson, 1923; Heron and Wheeler, 1964), as unconformable by others (for example, Brett and Wheeler, 1961), and as a ravinement by still others (for example, Swift, 1964; Swift and Heron, 1967, 1969; Swift and others, 1969).

To better understand, and perhaps to help resolve, the nature of the Black Creek-Peedee contact, we visited several exposures of the upper part of the Black Creek and basal part of the Peedee Formations along the Cape Fear River. During these visits we made detailed observations of the lithostratigraphic relationships within and among the exposures and collected invertebrate and palynomorph samples for use in biostratigraphic and paleoenvironmental interpretations. The results of our study suggest that the Black Creek and Peedee Formations are disconformable and that the two units were dominated by distinctly different environments of deposition; the disconformity is exposed along the Cape Fear River at three closely spaced outcrops between 49.5 and 50.25 river $\mathrm{mi}$ upstream from Wilmington, N. C.

It is our purpose to present the data upon which we base our conclusions and to suggest correlations for the upper part of the Black Creek and basal part of the Peedee Formations with Cretaceous units elsewhere in the Coastal Plain province other than the Carolinas. We make no effort in this report to relate our findings to areas outside the Cape Fear River region, nor do we imply that the ages, paleoenvironmental interpretations, and stratigraphic relationships between the Black Creek and Peedee Formations along the Cape Fear River can be extended to other areas of the Carolina Coastal Plain. We intend to treat these topics in future reports that will be prepared when we complete our ongoing investigations of the Upper Cretaceous Series as exposed along the Roanoke, Tar, Neuse, North 
East Cape Fear, Black, and Peedee Rivers of the Carolinas.

In this report, we follow the convention of using "right" and "left" bank as one faces downstream.

\section{Geographic Setting}

Most studies of the contact between the Black Creek and Peedee Formations in the Carolinas are based on paleoenvironmental interpretations of and physical and biostratigraphic correlations between exposures along the Cape Fear River at Walkers Bluff and a series of three closely spaced outcrops referred to as Donoho Creek, Robinsons, and Browns Landings (fig. 1).

At Walkers Bluff, located 60 river mi upstream from Wilmington, N.C., the Cape Fear River impinges against its right valley wall for a horizontal distance of approximately $0.75 \mathrm{mi}$, thereby exposing $45-55 \mathrm{ft}$ of Cretaceous sediments and 10-20 ft of shell marls of Pliocene and (or) Pleistocene age. Ten river mi downstream from Walkers Bluff, the Cape Fear River again impinges against its right valley wall, exposing both Cretaceous and post-Cretaceous sediments. This bluff, located between mileposts 50.25 and 49.5, is divided into three sections by two small tributaries to the Cape Fear River; in a downstream direction, these sections are referred to as Donoho Creek Landing, Robinsons Landing, and Browns Landing, respectively.

Between Walkers Bluff and the exposures at Donoho Creek, Robinsons, and Browns Landings, a horizontal distance of $7.3 \mathrm{mi}$, Stephenson $(1912,1923)$ noted the presence of Cretaceous sediments at three localities. Downstream (that is, upsection) from Walkers Bluff, these localities are Jessups Landing (milepost 56), an unnamed locality at milepost 53.5, and Deepwater Point (milepost 51.5). At Jessups Landing, 3-4 river mi downstream from Walkers Bluff, Cretaceous sands and clays overlain by gravelly alluvial (?) sand crop out for approximately $300 \mathrm{yd}$ along the left bank of the Cape Fear River. Lock and Dam No. 2, downstream from Donoho Creek Landing, was constructed after Stephenson's traverse of the river in 1907, and the presence of the dam has caused water level to rise sufficiently to drown the localities at milepost 53.5 and Deepwater
Point; at present, Jessups Landing is the only outcrop of Cretaceous sediments between Walkers Bluff and the exposures at Donoho Creek, Robinsons, and Browns Landings.

Data for our report come from stratigraphic interpretations and paleontologic analyses of samples from Walkers Bluff, Jessups Landing, Donoho Creek Landing, Robinsons Landing, and Browns Landing. In addition, we collected several samples of the fossiliferous marl and sandstone mentioned by Stephenson (1912, 1923) as occurring at Deepwater Point; these samples were collected with the use of snorkeling gear.

The positions of the localities along the Cape Fear River reported on herein are illustrated in figure 1, and detailed locality information is presented in table 1 .

\section{Previous Work}

The exposures between Walkers Bluff and Donoho Creek Landing are some of the most intensively studied Cretaceous sections in the Atlantic Coastal Plain. Several workers (for example, Stephenson, 1912, 1923; Brett and Wheeler, 1961; Heron and Wheeler, 1964) have provided measured sections and sedimentologic and (or) stratigraphic data for these exposures. Others (for example, Swift, 1964; Swift and Heron, 1967, 1969; Swift and others, 1969) have provided less detailed information regarding these sections but have referred to them in interpretations of the Late Cretaceous history of the Carolinas.

According to Stephenson (1912, 1923), the Black Creek Formation consists of thinly laminated, crossbedded ferruginous sand and carbonaceous clay. Lignite, amber, marcasite, and fossil leaves are common throughout the unit; glauconite is found in the unit but is not common or abundant. Horizontal and vertical changes between sand-dominated and clay-dominated facies are common and may be abrupt.

Marine invertebrate fossils have not been found in the lower part of the Black Creek Formation, but Stephenson $(1912,1923)$ observed the laminated sands and clays toward the top of the unit to be interstratified with lenses or beds of indurated calcareous sands and marls, some of which contain an abundant marine

TABLE 1.-Location of the Cape Fear River sections discussed in this report. Sections are presented in ascending stratigraphic order

\begin{tabular}{|c|c|c|c|c|c|c|c|c|c|c|}
\hline \multirow{2}{*}{ Section name } & \multirow{2}{*}{ Milepost } & \multirow{2}{*}{ Bank } & \multirow{2}{*}{ County } & \multicolumn{3}{|c|}{ North latitude } & \multicolumn{3}{|c|}{ West longitude } & \multirow{2}{*}{$\begin{array}{l}\text { 15-minute } \\
\text { quadrangle }\end{array}$} \\
\hline & & & & Degree & Minute & Second & Degree & Minute & Second & \\
\hline Walkers Bluff... & 60.0 & Right. & ...Bladen & $\ldots .34$ & 33 & 14 & 78 & 29 & 20 & White Lake \\
\hline Jessups Landing. & 56.0 & Left... & ....... do & 34 & 32 & 52 & 78 & 26 & 10 & Do. \\
\hline Deepwater Point & 51.5 & (1) & do & 34 & 29 & 31 & 78 & 24 & 35 & Bolton \\
\hline Donoho Creek Landing. & 50.25 & Right... & ..... do ................ & $\ldots .34$ & 28 & 26 & 78 & 24 & 40 & Do. \\
\hline Robinsons Landing & 49.75 & do .... & ....... do ................. & $\ldots .34$ & 28 & 04 & 78 & 24 & 10 & Do. \\
\hline Browns Landing & 49.5 & do .... & ....... do ................. & .... 34 & 28 & 00 & 78 & 23 & 54 & Do. \\
\hline
\end{tabular}

${ }^{1}$ Rocks now inundated. 


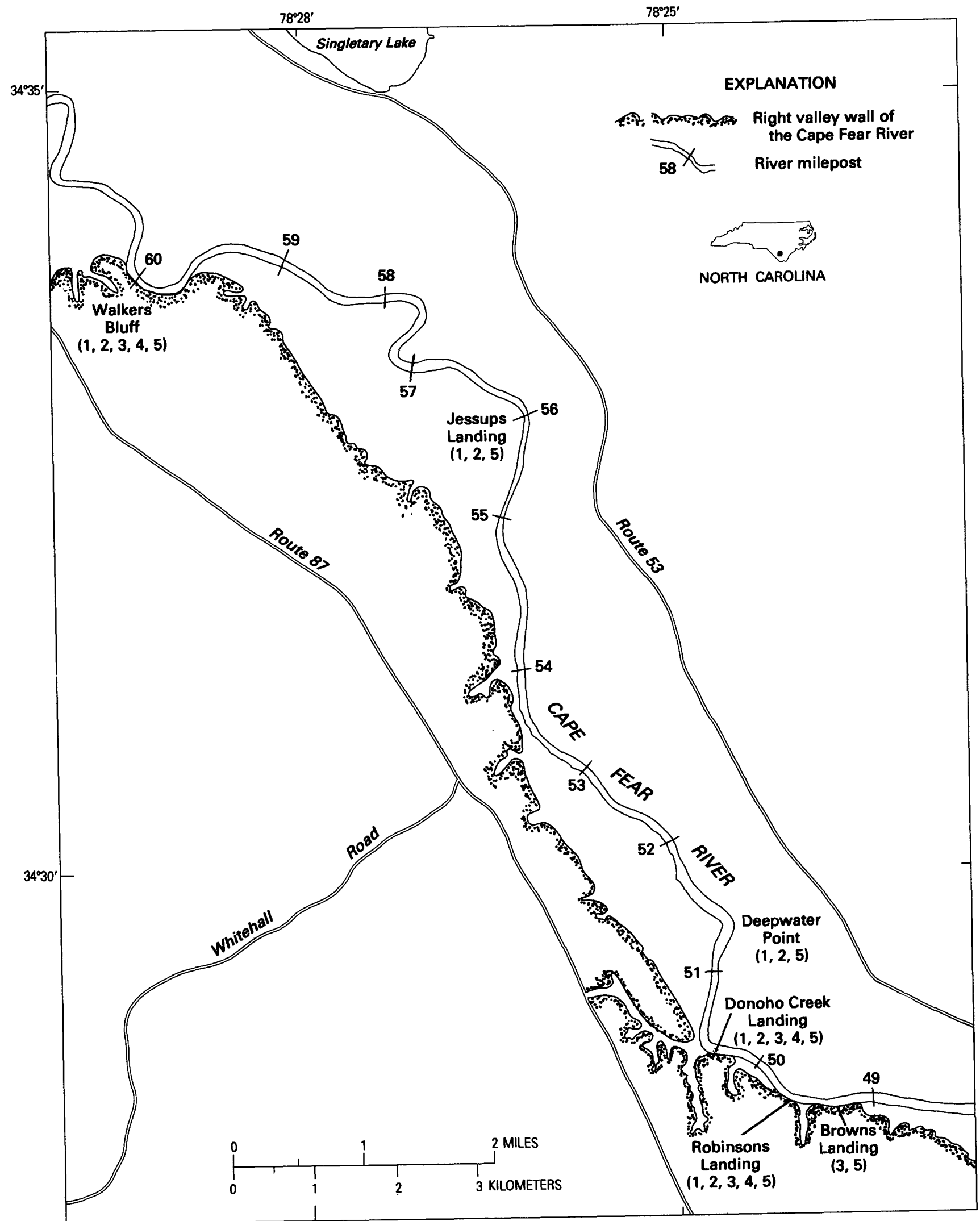

Figure 1.-Map of the Cape Fear River, N.C., between Walkers Bluff (milepost 60) and Browns Landing (milepost 49.5), showing the localities discussed in this report. The numbers in parentheses refer to publications in which stratigraphic and (or) paleontologic information was provided for that section: 1, Stephenson (1912); 2, Stephenson (1923); 3, Brett and Wheeler (1961); 4, Heron and Wheeler (1964); 5, this report. 
fauna. Stephenson (1923) assigned these fossiliferous beds to his "Snow Hill Calcareous Member," which is restricted to the upper part of the Black Creek Formation, and he considered them to have been deposited in a somewhat deeper water marine environment than was the lower, unfossiliferous part of the formation.

Stephenson $(1912,1923)$ reported the presence of these fossiliferous sandstones and marls of the "Snow Hill Calcareous Member" from several localities along the Cape Fear River. At Walkers Bluff (milepost 60), he observed a 1-ft-thick bed at the top of the section where, according to Stephenson's (1923) description, it is underlain by typical laminated, unfossiliferous sands and clays of the Black Creek Formation and is unconformably overlain by the Waccamaw Formation, which is early Pleistocene age according to Blackwelder (1979). Stephenson (1923) observed this sandstone to be discontinuous along the bluff and concluded that it changes laterally to an unfossiliferous loose sand. At the base of the exposure at Jessups Landing (milepost 56), Stephenson (1912) noted the presence of several feet of shell marl, overlain by $12 \mathrm{ft}$ of laminated, unfossiliferous sands and clays that he attributed to the Black Creek Formation. At the time of publication of his description of the Jessups Landing section (1912), the term "Snow Hill Calcareous Member" had not been introduced. However, the shell marl at the base of the section falls within his later (1923) circumscription of this unit. Stephenson $(1912,1923)$ also reported the occurrence of fossiliferous sandstones and shell marls at Deepwater Point (milepost 51.5), where, at the time of his visit,

"there is exposed at extreme low water a layer of greenish-gray, calcareous and fossiliferous rock about 1 foot in thickness, of marine origin. It is underlain by a dark, unconsolidated shell marl containing many sharks' teeth and fragile Cretaceous fossils, about 1 foot being exposed above the water.***" (Stephenson, 1912, p. 123).

At the base of the section at Donoho Creek Landing (milepost 50.25), Stephenson $(1912,1923)$ noted the occurrence of $10 \mathrm{ft}$ of dark blue, laminated, poorly fossiliferous Black Creek clays. These clays, he noted, were overlain by $26 \mathrm{ft}$ of the Peedee Formation, which he characterized throughout the Carolinas as a compact, dark-green or dark-gray, finely micaceous, glauconitic and argillaceous, fossiliferous, massive sand. Impure limestone beds and concretions and dark clays are also present in the Peedee Formation. From the massive bedding, contained fossils, and disseminated glauconite, Stephenson (1923) concluded that the Peedee Formation was deposited in open marine waters below wave base but above a depth of $\mathbf{5 0}$ fathoms.

From his observations of the sections between Walkers Bluff and Donoho Creek Landing, Stephenson
(1923) considered the contact between the Black Creek and Peedee Formations to be transitional, as he found no physical evidence of an unconformity or paleontologic evidence of a significant time-break between the two units. He concluded, therefore, that the Black Creek-Peedee contact represents a gradual transition from nearshore shallow marine bay and estuarine environments, represented by the lower part of the Black Creek Formation, to open marine conditions, represented by the Peedee Formation. The "Snow Hill Calcareous Member" is the transition between these two environments.

In an attempt to assess the stratigraphic relationships of the "Snow Hill Calcareous Member" to the Black Creek and Peedee Formations, Brett and Wheeler (1961) examined the stratigraphy, sedimentology, and paleontology of the Walkers Bluff, Donoho Creek Landing, and Browns Landing sections, in addition to sections from other areas of North Carolina. At Donoho Creek and Browns Landings, they observed a 6-in- to 6-ft-thick, poorly indurated, fossiliferous sandstone unconformably overlying the laminated Black Creek clays that occur at the base of both sections. They considered this sandstone to be the basal bed of the Peedee Formation, and, on the basis of their paleontologic and lithologic data, they considered it to be part of the same lithostratigraphic unit and deposited at the same time as the 1-ft-thick sandstone that caps the Cretaceous section at Walkers Bluff [which Stephenson (1923) placed in the "Snow Hill Calcareous Member" of the Black Creek Formation]. As a result of their investigation, Brett and Wheeler (1961) concluded that, between Walkers Bluff and Donoho Creek Landing, the contact between the Black Creek and Peedee Formations is unconformable and that an indurated calcareous sandstone marks the base of the Peedee Formation.

Despite their conclusion that an unconformity separates the Black Creek and Peedee Formations in the Cape Fear River region, Brett and Wheeler (1961) considered the upper part of the Black Creek and the basal part of the Peedee Formations to have been deposited during the same time interval (late Tayloran) and to represent a transition from a delta or near-delta distributary environment (the unfossiliferous, laminated carbonaceous clays of the Black Creek Formation) to a "beach," "inlet," or "upper-sound" environment (the basal sandstone of the Peedee Formation) to an "open lagoonal inlet" environment (the remainder of the Peedee Formation as exposed at Donoho Creek Landing). The sequence of transitional environments and the apparently synchronous nature of the upper part of the Black Creek and the lower part of the Peedee Formations led Brett and Wheeler (1961) to postulate that the 
Black Creek and Peedee Formations represent part of a single marine transgression that occupied the entire Late Cretaceous in North Carolina.

Heron and Wheeler (1964) agreed with Brett and Wheeler (1961) that, lithologically, the "Snow Hill Calcareous Member" as described by Stephenson (1923) should be placed in the Peedee Formation. However, in addition to the fossiliferous sandstone at the top of the Cretaceous part of the Walkers Bluff section previously noted by both Stephenson $(1912,1923)$ and Brett and Wheeler (1961), Heron and Wheeler (1964) also observed scattered shells in a 2- to 3-ft-thick bed of medium- to coarse-grained sand approximately $20 \mathrm{ft}$ below the sandstone at the top of the section. By definition, this lower sand would be included in the "Snow Hill Calcareous Member" of Stephenson (1923), but, because Brett and Wheeler (1961) had placed the "Snow Hill" in the basal part of the Peedee Formation, Heron and Wheeler (1964) placed the Black Creek-Peedee contact at the base of this sand. As this lower sand appears to be conformable with a laminated clay below, Heron and Wheeler (1964) concluded that, at Walkers Bluff, the Black Creek-Peedee contact is conformable and that "[i]t is difficult to place a finger on an unequivocal lithologic boundary" between these units (Heron and Wheeler, 1964, p. 46).

At Donoho Creek Landing, however, Heron and Wheeler (1964) recognized the unconformity that Brett and Wheeler (1961) considered to mark the Black Creek-Peedee contact. This unconformity occurs between the undisputed Black Creek clays at the base of the section and the 1-ft-thick sandstone that Brett and Wheeler (1961) considered as marking the base of the Peedee Formation. According to Heron and Wheeler (1964 p. 46), the unconformity is characterized by phosphate nodules, large specimens of Ostrea pratti, and "unusual small soft discs of sand***." They further observed that neither the unconformity nor the basal sandstone of the Peedee Formation is as conspicuous everywhere as each is at Donoho Creek Landing. At Robinsons Landing, just $0.5 \mathrm{mi}$ downstream from Donoho Creek Landing, Heron and Wheeler (1964) found no physical evidence of the unconformity, but they noted that the contact between the Black Creek and Peedee Formations is marked by the presence of bedding in the Black Creek Formation and a 3-ft-thick fossiliferous zone at the base of the Peedee Formation that apparently occupies the same stratigraphic position as does the basal sandstone at Donoho Creek Landing. For a distance of $0.5 \mathrm{mi}$ upstream from Donoho Creek Landing, however, Heron and Wheeler (1964) noted blocks of the basal part of the Peedee sandstone scattered along the water's edge.

As had Brett and Wheeler (1961), Heron and
Wheeler (1964) concluded that the Black Creek and Peedee Formations are transitional, and, as such, they are evidence that the entire Upper Cretaceous Series of the Carolinas represents a single marine transgression. Their reasoning included not only the apparently transitional nature of the contact but the time of deposition of the units. According to their reasoning:

1. Stephenson (1923) placed the Black Creek Formation, including its upper "Snow Hill Calcareous Member," in the Exogyra ponderosa Zone of Tayloran Age and the Peedee Formation in the E. costata Zone of Navarroan Age.

2. Brett and Wheeler (1961) removed the "Snow Hill Calcareous Member" from the Black Creek Formation and placed it in the Peedee Formation. As a result, the Peedee Formation, as defined by Brett and Wheeler (1961), includes rocks of both Tayloran Age (the "Snow Hill") and Navarroan Age (the remainder of the Peedee Formation).

3. Therefore, because the Black Creek Formation is of Tayloran Age and the Peedee Formation, including the "Snow Hill," is of both Tayloran and Navarroan Age, these two units must be time transgressive.

Swift (1964), Swift and Heron (1969), and Swift and others (1969) accepted and expanded upon the hypotheses advanced by Brett and Wheeler (1961) and Heron and Wheeler (1964). Specifically, they agreed with the previously drawn conclusions that the Black Creek and Peedee Formations represent part of a single Late Cretaceous marine transgression and that the "Snow Hill Calcareous Member" lithologically and paleoenvironmentally belongs to the basal part of the Peedee Formation rather than to the upper part of the Black Creek Formation.

In a series of sedimentologic studies aimed at interpreting the environments of deposition of the Cretaceous formations of the Carolinas, these workers recognized three environments (or lithosomes) within the Black Creek Formation (an estuarine, a lagoonal, and a littoral lithosome; Swift and Heron, 1967) and three within the Peedee Formation (a proximal-shelf, a distal-shelf, and a shelf-mud lithosome; Swift and others, 1969). With regard to these lithosomes, Swift and Heron (1967) and Swift and others (1969) interpreted the sections between Walkers Bluff and Donoho Creek Landing as follows:

1. The laminated sands and clays at the base of the sections at Walkers Bluff, Donoho Creek Landing, and Robinsons Landing represent an estuarine depositional environment. This lithosome is interpreted as being fluviomarine in origin; it is characteristic of tidally influenced upper-delta and estuarine environments that reflect both wave- and river-generated currents. 
2. The "Snow Hill Calcareous Member" at the top of the Cretaceous part of the Walkers Bluff section (considered as the basal beds of the Peedee Formation) represents a proximal-shelf environment, characterized by poorly sorted, medium-grained, bioturbated sands that contain horizons of coarser grained material. The coarser, gravelly horizons consist of megaclasts of tightly packed mollusk shells, shark teeth, very fine grained quartz pebbles, lignite, reptile bone fragments, and pebblesized clay clasts.

3. The Peedee Formation that forms the top of the section at Donoho Creek Landing [that is, above the unconformity recognized by Brett and Wheeler (1961) and Heron and Wheeler (1964)] represents a distal-shelf environment. This environment is characterized by very fine to fine-grained, bioturbated sands that may contain as much as 50 percent clayey silt matrix.

The presence of the unconformity documented by Brett and Wheeler (1961) and Heron and Wheeler (1964) at Donoho Creek Landing suggested to Swift (1964) and Swift and Heron (1969) that the relationship among these three lithosomes, and hence the contact between the Black Creek and Peedee Formations, is a ravinement. According to this interpretation, the lowenergy marsh and lagoonal sediments and the highenergy barrier-island sands, all of which were deposited at the margins of the Late Cretaceous sea, were destroyed as the sea transgressed over them. As a result, the proximal- and distal-shelf deposits of the Peedee Formation disconformably overlie the nearshore deposits of the Black Creek Formation. In support of this interpretation, Swift and Heron (1969) cited the faunal composition of the "Snow Hill Calcareous Member" as described by Stephenson (1923) from Walkers Bluff and interpreted by Brett and Wheeler (1961) as representing an open-lagoonal environment. Faunally, the "Snow Hill" contains a diverse invertebrate assemblage that reflects both lagoonal components reworked from the open lagoonal environment destroyed by the trangressing sea and components indigenous to the proximal-shelf environment of the "Snow Hill." Hence, Swift (1964), Swift and Heron (1969), and Swift and others (1969) regarded the Black Creek and Peedee Formations as representing part of a single Late Cretaceous transgression in which the nearshore deposits of the uppermost part of the Black Creek Formation were cannibalized by the transgressing Peedee sea, resulting in a disconformity, or ravinement, between the two units. In accordance with the interpretation of the Black Creek-Peedee contact as a ravinement, the hiatus between the two units is of an insignificant duration, at least in the Cape Fear River region.

\section{SECTION DESCRIPTIONS}

Seven sections were measured along the Cape Fear River; three at Walkers Bluff and one each at Jessups, Donoho Creek, Robinsons, and Browns Landings. Complete descriptions of the lithologic units recognized at these exposures are presented under the heading "Measured sections" at the end of this report; diagrammatic interpretations of the sections are presented as figures 2-4 and 6-9. Because the outcrop noted by Stephenson (1923) at Deepwater Point is now under water, we could not interpret the stratigraphic relationships of the sandstones and marls present at this locality. We did, however, recover samples of both marl and sandstone from Deepwater Point; their lithologies are described in this section.

A total of 23 invertebrate and 16 palynomorph samples were collected and analyzed from the seven measured sections and from Deepwater Point. The stratigraphic positions of the samples relative to the measured sections are shown in figures $2-4$ and 6-9. The stratigraphic distribution of the invertebrate fossils recovered from the samples is presented in table 2 , and the palynomorph data is presented in table 3.

Table 2 is a complete listing of the invertebrate fauna recovered from the Walkers Bluff to Browns Landing sections. The palynomorphs listed in table 3 , however, represent only those taxa we consider conspecific with those illustrated by Wolfe (1976) from the northern Atlantic Coastal Plain. Wolfe (1976) did not apply generic and specific names to his "species"; instead, he assigned each an alphanumeric code. However, his is the only pollen zonation presently available for the Campanian and Maestrichtian Stages of the Atlantic Coastal Plain. Therefore, for purposes of palynologic correlation, we find it necessary to compare the assemblages from the Cape Fear River sections with those described by Wolfe (1976) from the Raritan and Salisbury embayments of the northern Atlantic Coastal Plain.

\section{Walkers Bluff}

Although much of Walkers Bluff was covered with vegetation at the time of our visits (October 1979, April and August 1980, March 1981), the areas seen indicated a great deal of lateral variation in lithology and bedding character within the Cretaceous part of the section. For this reason, we made detailed measurements and observations at three localities along the face of the bluff. At the upstream end, we measured a section 100 $y d$ from where the bluff diverges from the river. About $0.5 \mathrm{mi}$ downstream from this locality was another nearly complete exposure of Cretaceous sediments, 
TABLE 2.-Distribution of megainvertebrate fossils and vertebrate remains in the outcropping Cretaceous sections along the Cape Fear River, N.C., between Walkers Bluff and Browns Landing

$[+$, presented but abundance not recorded; $R$, rare occurrence (1-3 specimens); $F$, few specimens recorded (4-10 specimens); $\mathrm{C}$, common occurrence (11-25 specimens); A, abundant occurrence ( $\geq 26$ specimens)]

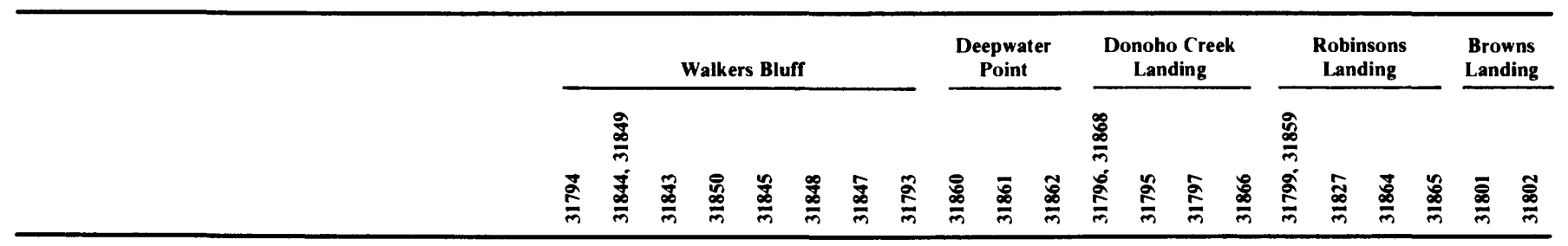

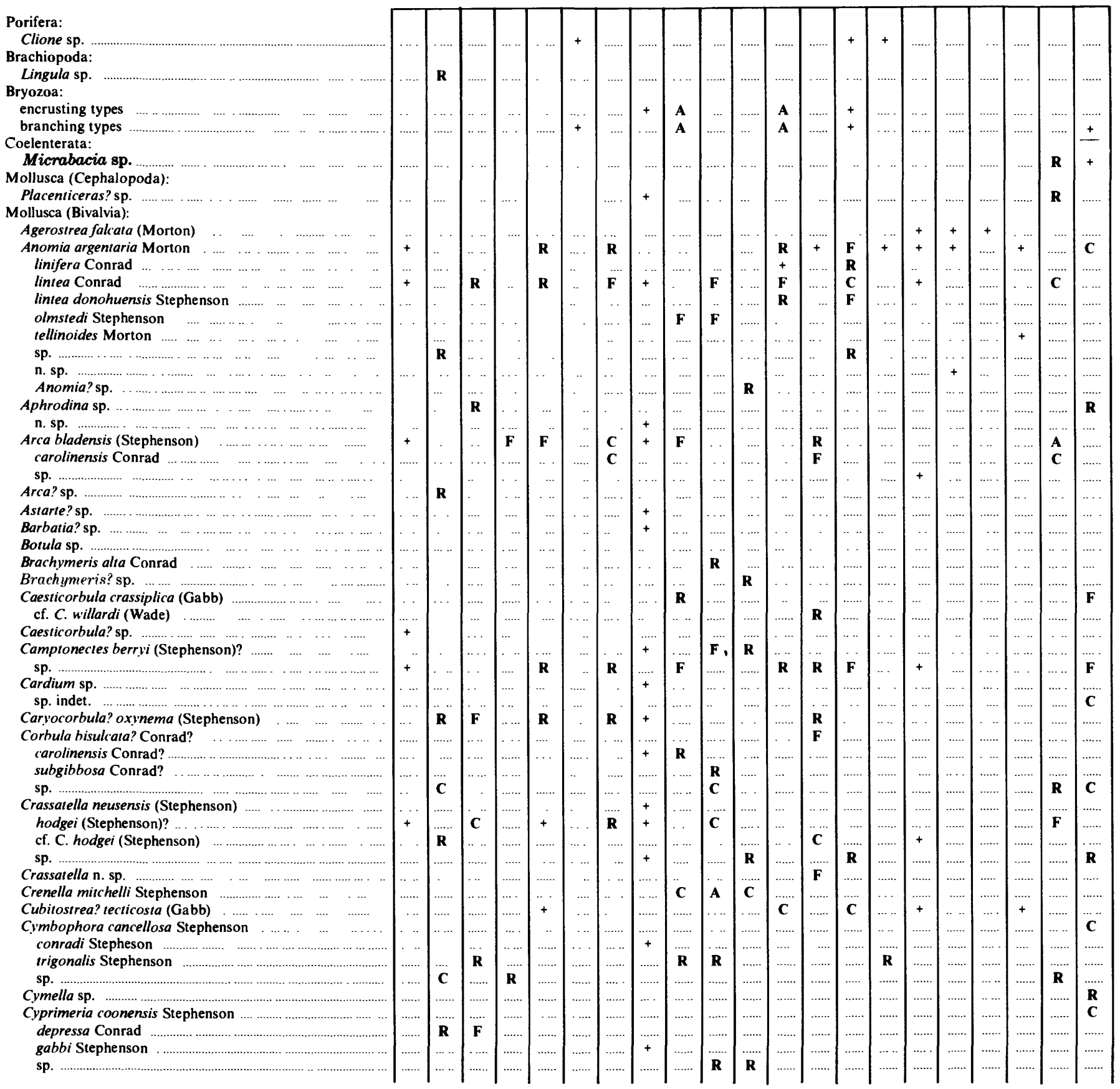


TABLE 2.-Distribution of megainvertebrate fossils and vertebrate remains in the outcropping Cretaceous sections along the Cape Fear River, N.C., between Walkers Bluff and Browns Landing-Continued

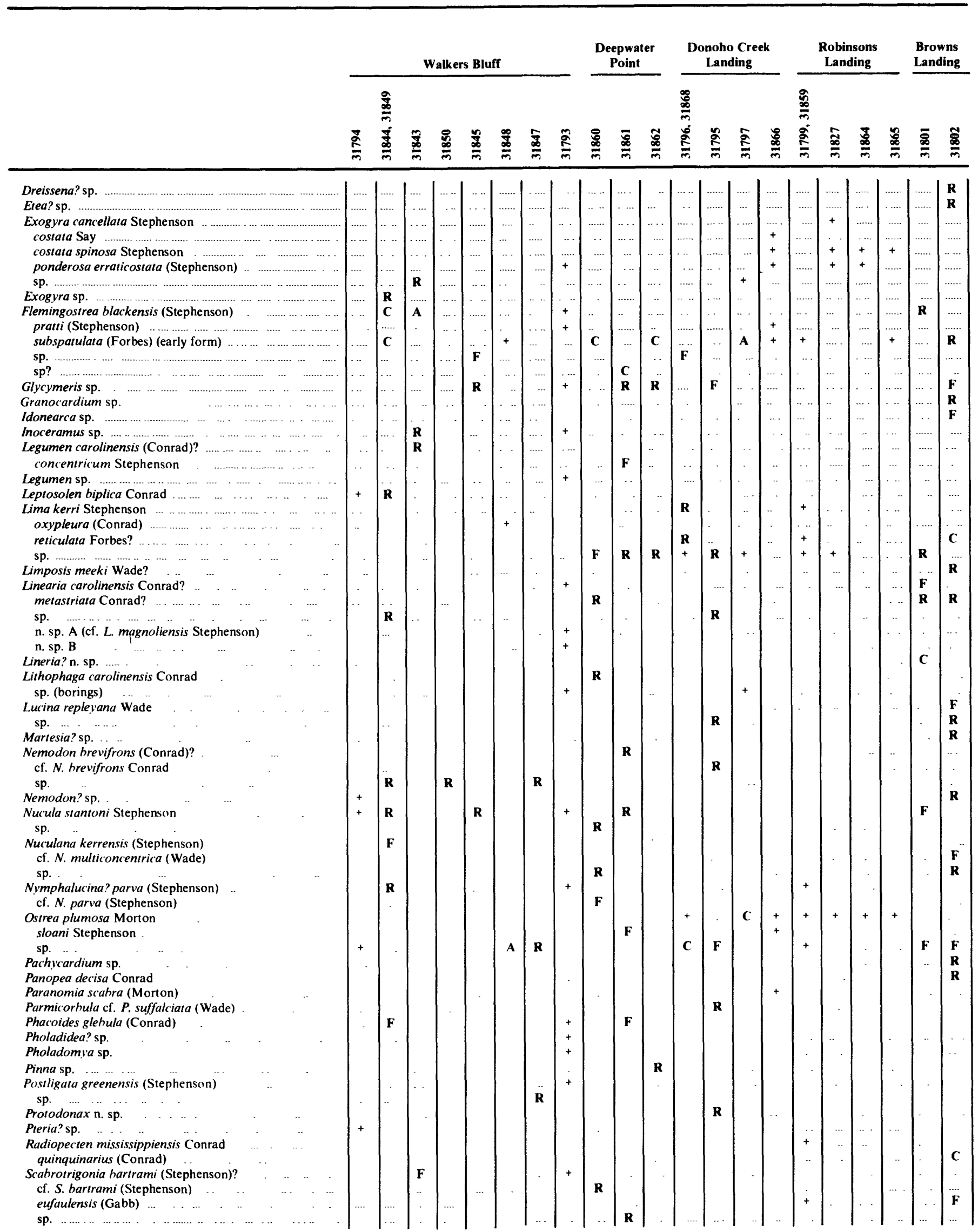




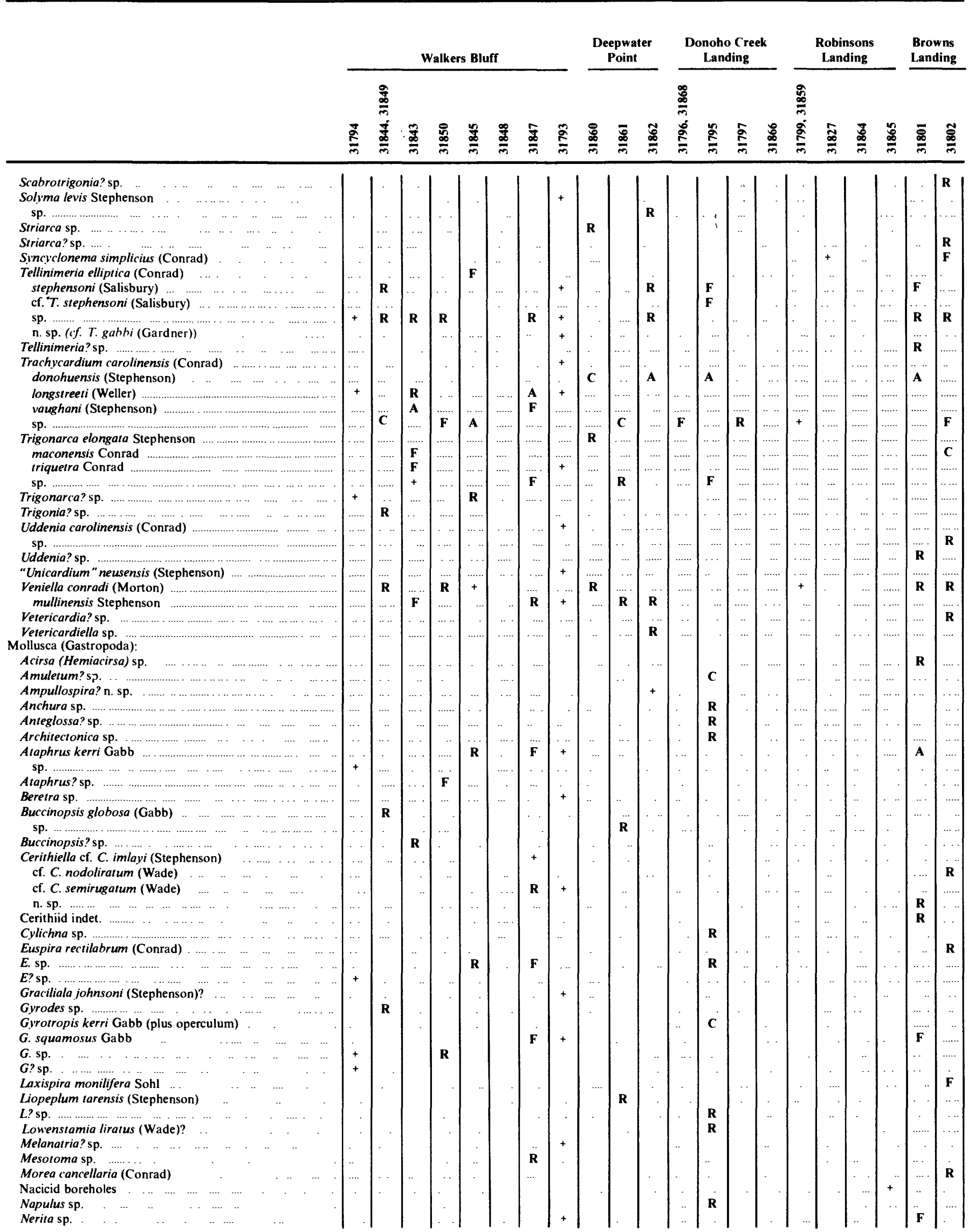


TABLE 2.-Distribution of megainvertebrate fossils and vertebrate remains in the outcropping Cretaceous sections along the Cape Fear River, N.C., between Walkers Bluff and Brouns Landing-Continued

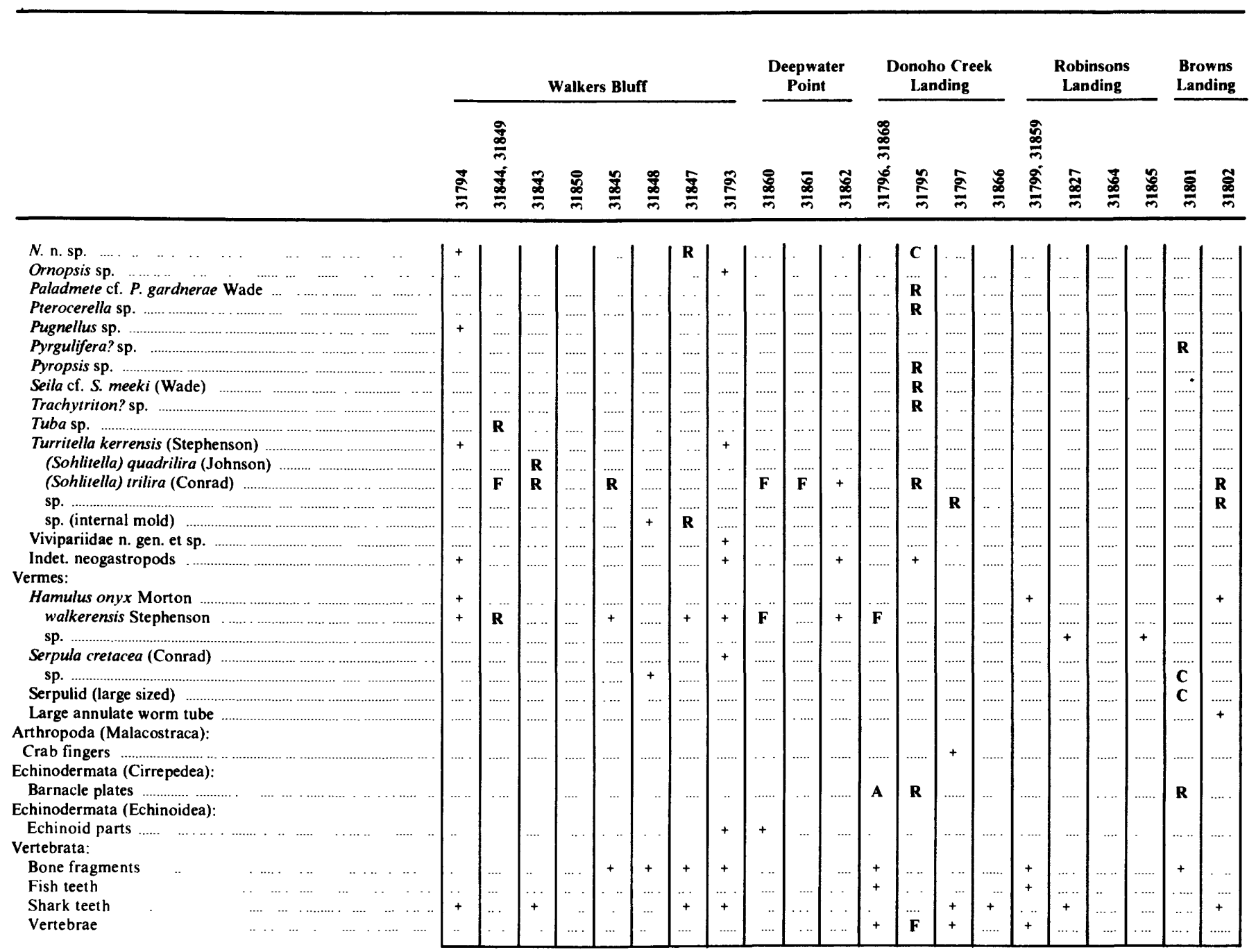


TABLE 3.-Distribution of biostratigraphically important pollen species in the outcropping Cretaceous sections along the Cape Fear River, N.C., between Walkers Bluff and Browns Landing

[The alphanumeric code assigned to each species by Wolfe (1976) is in parentheses after the binomen]

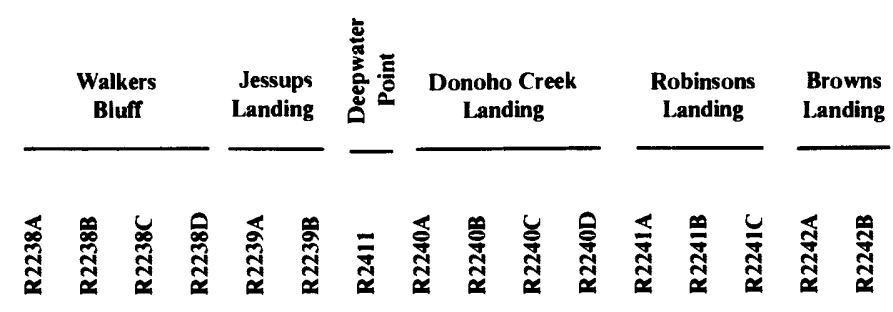

Baculostephanocolpites sp. A (MPH-1) Betulaceoipollenites sp. A. (NO-3)

Brevicolporites sp. B (CP3F-2)

Casuarinidites sp. A (NO-2)

sp. B (NO-5)

Choanopollenites

cf. C. conspicuus Tschudy (NA-8)

sp. A (NA-3)

sp. E (NA-7)

Complexiopollis abdita Tschudy (NB-1)

Extremipollis viva Tschudy (NJ-2)

Holkopollenites

cf. H. chemardensis Fairchild (CP3D-3)

? Holkopollenites sp. C (CP3E-1)

Labrapollis sp. A (NV-1)

Osculapollis aequala Tschudy (NO-1)

Plicapollis usitata Tschudy (NE-3)

aff. Plicapollis sp. A (NN-1)

?Plicapollis sp. C (ND-3)

Proteacidites sp. A (PR-1)

sp. D (PR-4)

sp. G (PR-7)

Pseudoplicapollis endocuspa Tschudy (NC-2) serena Tschudy (NC-3)

sp. A (NC-1)

Pseudovacuopollis involuta Tschudy (NT-1)

"Retitricolpites"sp. H (C3B-3)

"Retitricolpites"sp. L (C3C-3)

Triatriopollenites sp. A (NP-1)

sp. B (NP-2)

Tricolporites sp. K (CP3B-8)

- Triporate type $\mathrm{A}(\mathrm{NU}-1)$

?Trudopollis sp. A (NF-2) and

Endoinfundibulapollis distincto

Tschudy (NM-1)

Relative frequency of abundance (in percent) of dinoflagellates and acritarchs

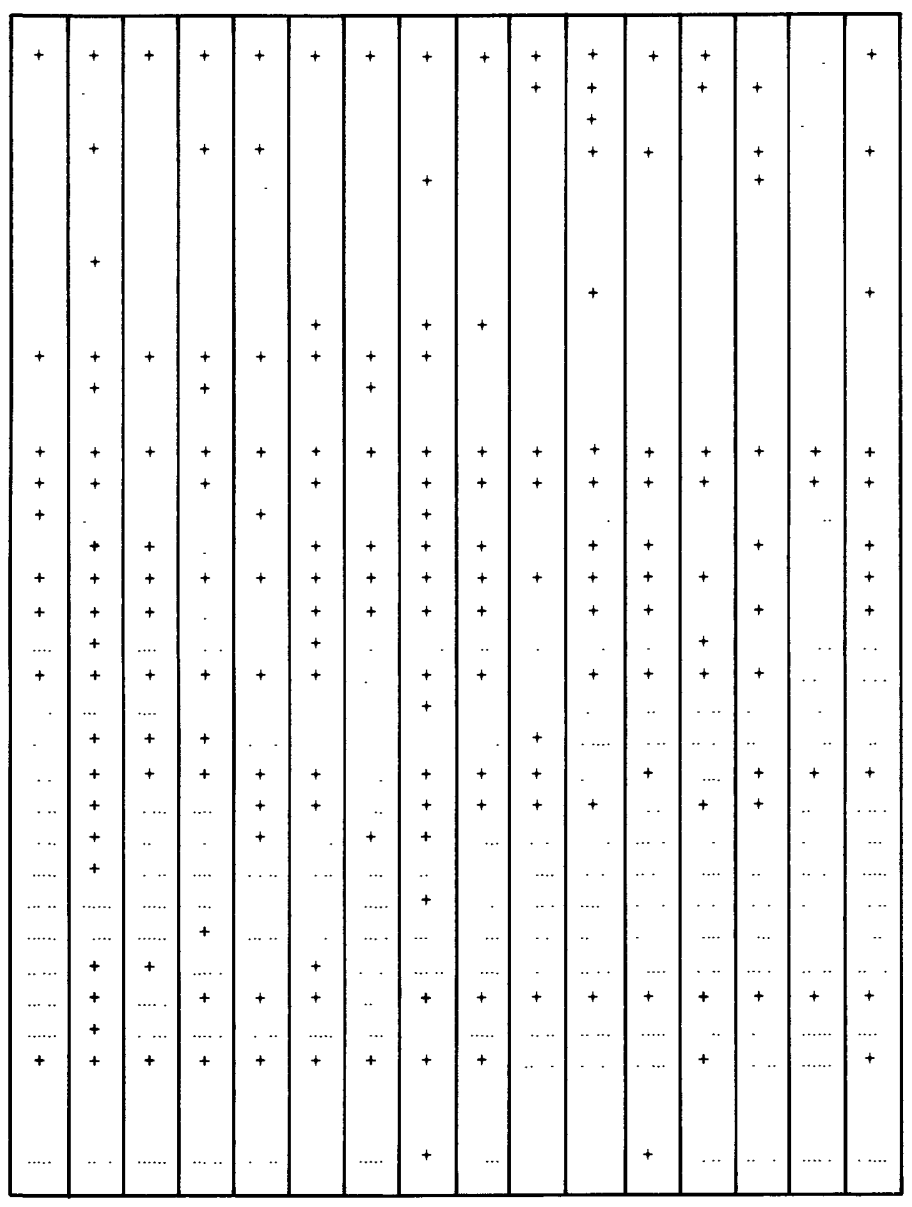


which we refer to as the medial section. The downstream section is located 200 yd downriver from the medial section.

\section{STRATIGRAPHIC COLUMN, UPSTREAM SECTION}

At this exposure, we differentiated five lithologic units within the Cretaceous (units 1-5 of fig. 2) overlain by Neogene shell marls of the Waccamaw Formation of early Pleistocene age (unit 6 of fig. 2).

\section{STRATIGRAPHIC COLUMN, MEDIAL SECTION}

At this exposure, which is the highest outcrop along the bluff, we recognized three Cretaceous units, overlain by the Waccamaw Formation (units 1-4 of fig. 3).

\section{STRATIGRAPHIC COLUMN, DOWNSTREAM SECTION}

The Waccamaw marls and shell beds that overlie the Cretaceous deposits at the upstream and medial sections (unit 6 of fig. 2 and unit 4 of fig. 3, respectively) are absent in the main bluff face at the downstream section (fig. 4). Hence, the contact between the Cretaceous and the overlying unit, if present in the main bluff face, cannot be accurately located. At the extreme upriver end of the exposure, however, we observed one large float block of sandstone that is lithically and faunally like those incorporated in the basal part of the Waccamaw of the medial bluff section. At the downstream exposure, stratigraphic relationships are somewhat obscure, but there is a suggestion that the Waccamaw has been removed by channelling and that younger clastic sediment has filled the channel. This interpretation is supported by the reappearance of the Waccamaw Formation high on the heavily wooded slopes downriver from the main downstream bluff, where the basal marl again contains transported sandstone blocks and disconformably overlies the Cretaceous sands.

\section{PALEONTOLOGY}

Eight of the fossiliferous horizons from the Cretaceous part of the Walkers Bluff section were sampled and analyzed for their invertebrate fauna, and four samples of the carbonaceous clay were collected for palynological analysis (see figs. 2-4 for the stratigraphic location of the paleontologic samples and tables 2 and 3 for a listing of their contained fauna and palynomorphs). In addition, analyses were made of the fossils contained in the sandstone blocks incorporated in the basal part of the Waccamaw Formation at the medial section, as preliminary field examination revealed that the blocks contain a fauna of Late Cretaceous age.

Sample 31794 (U.S. Geological Survey Mesozoic
Invertebrate Collection Number) was taken from a lenticular sandstone 8 to $10 \mathrm{ft}$ above water level. This sandstone occurred as float on the face of the bluff, and we are uncertain as to whether it was derived from the series of discontinuous lenses of sandstone at the top of unit 1 of the downstream section or from an undetected sandstone within the laminated sands and clays of unit 1.

Fossils in samples 31844,31849 , and 31850 (all from the downstream section) occur only as impressions, whereas shell material was recovered from all other samples.

More than 75 species of spores and pollen were recorded from the Walkers Bluff samples. Of these, we consider only 23 to be conspecific with forms illustrated by Wolfe (1976) from the Raritan and Salisbury embayments. Dinoflagellates and acritarchs were also observed in the palynologic samples, and their abundance relative to terrestrially derived spores and pollen is presented in table 3 .

\section{DISCUSSION}

The lithologic and paleontologic data from the Walkers Bluff sections suggest that vertical and lateral facies changes within the bluff are rapid and, in some places, abrupt, especially in the upper part of the section. The stratigraphic relationships among the three measured sections (fig. 5) were determined by walking along the face of the bluff and observing the physical relationships among the units.

The only laterally persistent lithologic unit at Walkers Bluff is the laminated sand and carbonaceous clay sequence at the base of all three sections. Although the basal few feet of the bluff are covered by vegetation, scattered exposures suggest that the laminated sequence extends to, and probably below, water level.

Vertical facies changes are well illustrated at the downstream section. In addition to the lithologic evidence for an abrupt change from the lower energy conditions of unit 1 to the higher energy conditions of unit 2 (and possibly unit 3), the paleontologic data provide information concerning the paleoenvironments of these units. The fauna recovered from the upper part of unit 1 (samples 31844 and 31849 ) is diverse; there is a dominantly infaunal assemblage of both deposit feeders (Nuculana, Tellina, Linearia) and suspension feeders (Lucina, Veniella, Cyprimeria). The presence of these elements indicates a stable substrate rich in organic material. The discontinuous sandstone lenses at the top of unit 1 contain an assemblage (sample 31843 ) of proportionately more epifaunal elements (Flemingostrea, Exogyra, Inoceramus) and shallow, burrowing bivalves (Scabrotrigonia, Trachycardium) than are found below, 


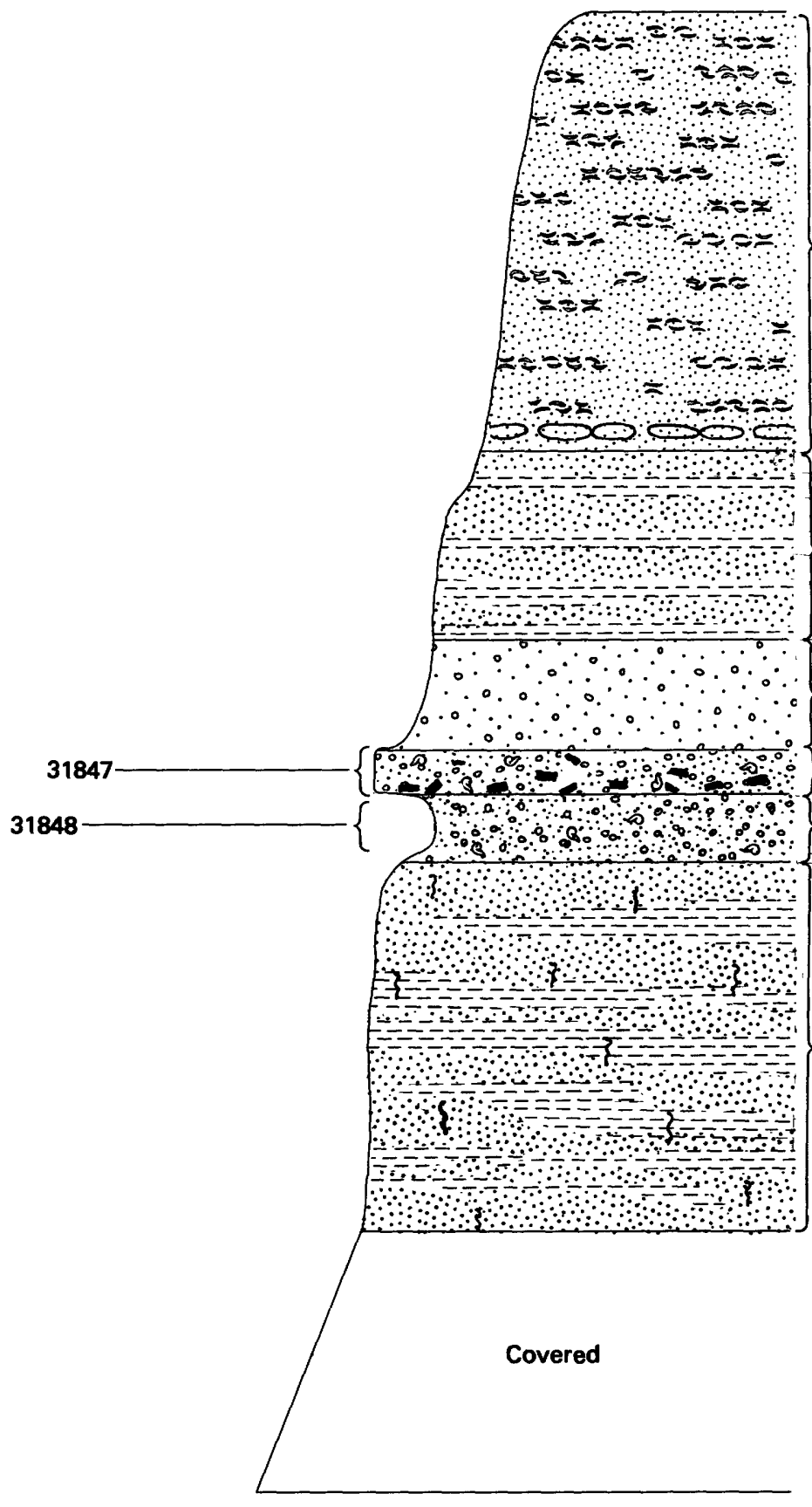

6. Shell and sandy shell marl containing reworked blocks of sandstone at the base.

5. Laminated sand and carbonaceous clay.

4. Sand, medium-grained, subangular, well-sorted, unfossiliferous, massive.

3. Sandstone, medium- to coarse-grained, angular to subrounded, poorly sorted, fossiliferous, crossbedded to massive.

2. Sand, coarse-grained, subangular, poorly sorted, fossiliferous, crossbedded.

1. Sand containing laminated carbonaceous clay.

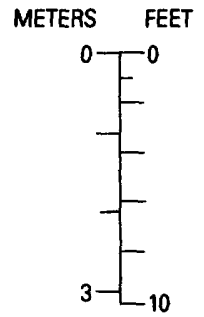

EXPLANATION

\begin{tabular}{|c|c|c|c|c|c|}
\hline $\begin{array}{l}=\approx== \\
2=0\end{array}$ & Shell & $\because \because \because 0$ & $\begin{array}{l}\text { Medium-grained } \\
\text { sand }\end{array}$ & & Wood fragments \\
\hline$E=-=-$ & Clay & 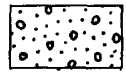 & $\begin{array}{l}\text { Medium- to coarse- } \\
\text { grained sandstone }\end{array}$ & $1,1,1$ & Burrows \\
\hline & Sand & 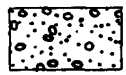 & $\begin{array}{l}\text { Coarse-grained } \\
\text { sand }\end{array}$ & & \\
\hline
\end{tabular}

FIGURE 2.-Stratigraphic column of the upstream section exposed at Walkers Bluff. U.S. Geological Survey Mesozoic Invertebrate Collection Numbers are to the far left of the column. Lithologic unit numbers are to the right of the column. 


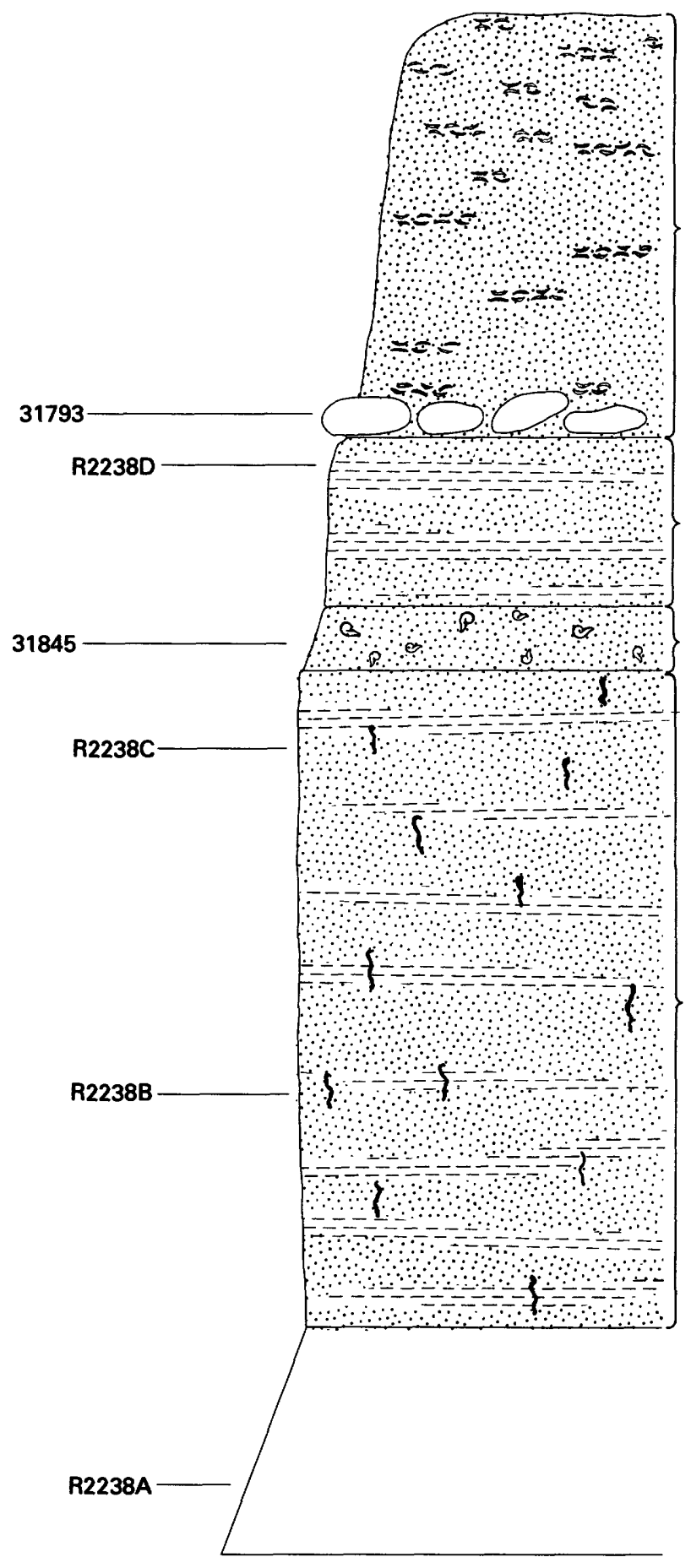

4. Shell and sandy shell marl containing reworked blocks of sandstone at the base.

3. Laminated clay and sand.

2. Sand, fine-grained, angular to subangular, well-sorted, fossiliferous, massive.

1. Sand containing laminated carbonaceous clay.

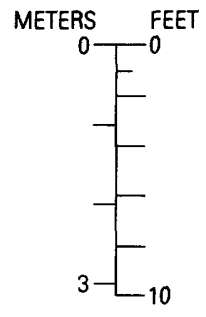

EXPLANATION

\begin{tabular}{|c|c|c|c|}
\hline $\begin{array}{l}\text { Eニンニ- } \\
\text { ニ=ニ }\end{array}$ & Shell & $\begin{array}{l}E==-1 \\
===-1 \\
===-1\end{array}$ & Clay \\
\hline \begin{tabular}{|llll}
$\because \ddots \ddots$ \\
\hdashline & $\ddots$
\end{tabular} & Sand & $13,3 ?$ & \\
\hline
\end{tabular}

FIGURE 3.-Stratigraphic column of the medial section exposed at Walkers Bluff. U.S. Geological Survey Mesozoic Invertebrate Collection Numbers are to the far left and U.S. Geological Survey Paleobotanical Collection Numbers are to the near left of the column. Lithologic unit numbers are to the right of the column. 


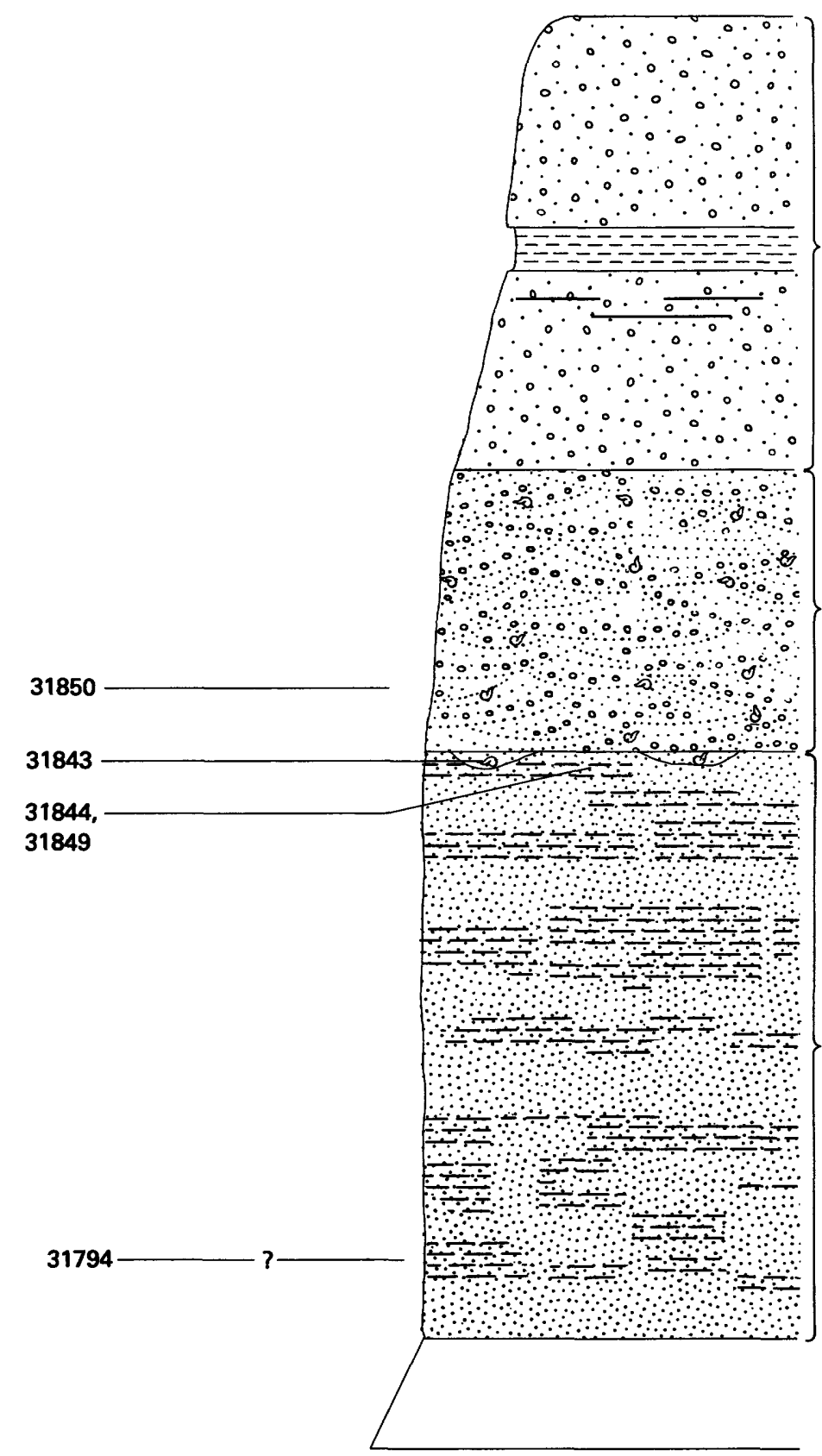

3. Sand, fine- to medium-grained, subangular, poorly to wellsorted, unfossiliferous, massive; a 2-foot-thick clay bed is present 10 feet from the top of the unit.

2. Sand, medium-grained, subangular, poorly sorted, fossiliferous, crossbedded; fossils are present as impressions in clay drapes along bedding planes.

1. Sand containing laminated carbonaceous clay; discontinuous fossiliferous sandstone lenses are present at the top of the unit.

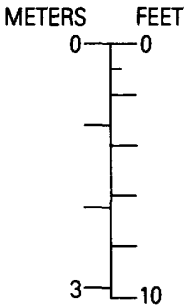

EXPLANATION

\begin{tabular}{|c|c|c|c|c|c|}
\hline$==1$ & Clay & $\therefore \because \because 9$ & $\begin{array}{l}\text { Fine- to medium- } \\
\text { grained sand }\end{array}$ & \begin{tabular}{|llll} 
& 0 & 0 \\
\hdashline & $\ddots$ & 0 \\
\hdashline & $\ddots$ & 0 & 0 \\
\hdashline & 0 & 0
\end{tabular} & Crossbedding \\
\hline & Sand & 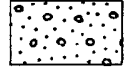 & $\begin{array}{l}\text { Medium-grained } \\
\text { sand }\end{array}$ & & \\
\hline
\end{tabular}

FIGURE 4.-Stratigraphic column of the downstream section exposed at Walkers Bluff. U.S. Geological Survey Mesozoic Invertebrate Collection Numbers are to the far left of the column. Lithologic unit numbers are to the right of the column. 

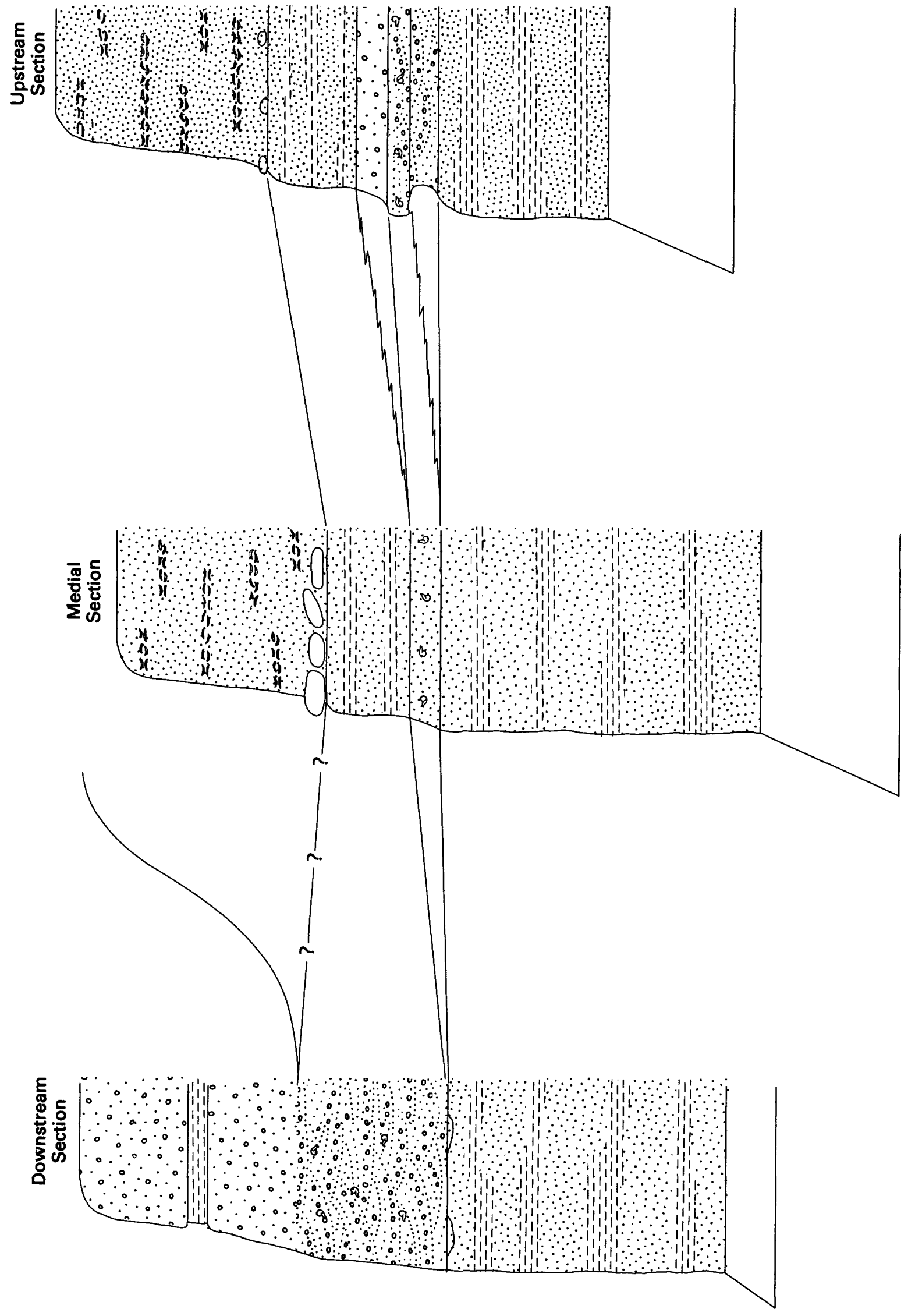
suggesting a less stable substrate and perhaps shallower water depths than those of the laminated sequence. The overlying crossbedded sands contain a less diverse, transported assemblage that, when coupled with the bedding features, confirms a vertical facies change from the low-energy, organic-rich, stable substrate environment of unit 1 to the high-energy, unstable substrate environment of unit 2 .

Lateral facies changes are illustrated by the fauna contained in the sands and sandstones that overlie the basal laminated sequence (samples 31848 and 31847 of the upstream section and sample 31845 of the medial section). In an upstream direction, there is an increase in the relative abundance of arcoids and cardiids, which is suggestive of increased substrate instability. The presence of Nerita (a common intertidal form) in the sandstone of the upstream section is further evidence of higher energy conditions at this locality.

$$
\text { Jessups Landing }
$$

\section{STRATIGRAPHIC COLUMN}

Only two lithologic units are differentiated at Jessups Landing (units 1 and 2 of fig. 6 ).

\section{PALEONTOLOGY}

No megafossils were observed at Jessups Landing, but two samples were taken from the carbonaceous clays within the Cretaceous part of the section (that is, unit 1). The stratigraphic positions of the samples are indicated in figure 6, and the biostratigraphically important species recovered from the samples are listed in table 3 . The relative abundance of dinoflagellates and acritarchs is presented in table 3.

\section{DISCUSSION}

We did not observe the fossiliferous marl mentioned by Stephenson (1912) as cropping out at the base of the section at Jessups Landing before construction of the lock and dam system. For this reason, we are unable to relate these marls lithologically, paleontologically, or paleoenvironmentally to any of the fossiliferous units at Walkers Bluff.

As they are at Walkers Bluff, lateral and vertical facies changes from crossbedded sands to laminated clay lenses or beds are both rapid and abrupt at Jessups Landing. We did not observe any of the crossbed sets or clay beds to be continuous across the entire outcrop.

\section{Deepwater Point}

The fossiliferous marls and sandstones pictured by Stephenson (1912; 1923, pl. 5, fig. 13) from Deepwater
Point no longer crop out; they have been covered by water that has backed up owing to the construction of Lock and Dam No. 2 on the Cape Fear River. However, we located these units on the river bottom, and, by diving, two samples of marl and one of sandstone were collected for analysis of their megafossil content. One sample of marl was also used for palynologic analysis.

\section{LITHOLOGIC DESCRIPTIONS OF THE SAMPLES}

Although we cannot provide a measured section for the rocks exposed along the river bottom at Deepwater Point, the lithology of the samples collected can be described as follows:

Sample 31860: Silty, fine-grained, gray, fossiliferous sandstone containing pockets (burrows?) of glauconitic, carbonaceous, coarse-grained sand. Clasts of carbonaceous clay and worn phosphate nodules are present.

Sample 31861: Unconsolidated, gray, sparingly glauconitic, fossiliferous, medium- to coarse-grained, angular quartz sand; some granule-sized quartz grains are present.

Sample 31862: Light-gray, glauconitic, silty, fossiliferous, medium-grained sand. Small phosphate pebbles and abraded pieces of wood and bone are present.

\section{PALEONTOLOGY}

Samples 31860 and 31861 were analyzed only for their megafossil content; sample 31862 was analyzed for both megafossils and palynomorphs (this sample has also been assigned U.S. Geological Survey Paleobotanical Collection Number R2411). The megafossils present in these samples are listed in table 2 , and the biostratigraphically important palynomorphs recovered from sample 31862 (R2411) are listed in table 3, where the relative abundance of dinoflagellates and acritarchs in the sample is also given.

\section{Donoho Creek Landing \\ STRATIGRAPHIC COLUMN}

Approximately $30 \mathrm{ft}$ of Cretaceous sediments are exposed at Donoho Creek Landing (that is, Donohue Creek Landing of Stephenson, 1912, 1923), within which we recognized seven lithologic units (units 1-7 of fig. 7). The Cretaceous units are overlain by $10 \mathrm{ft}$ of alluvial(?) deposits (unit 8 of fig. 7).

\section{PALEONTOLOGY}

Five megafossil collections were taken from four of the fossiliferous sands that occur at Donoho Creek 


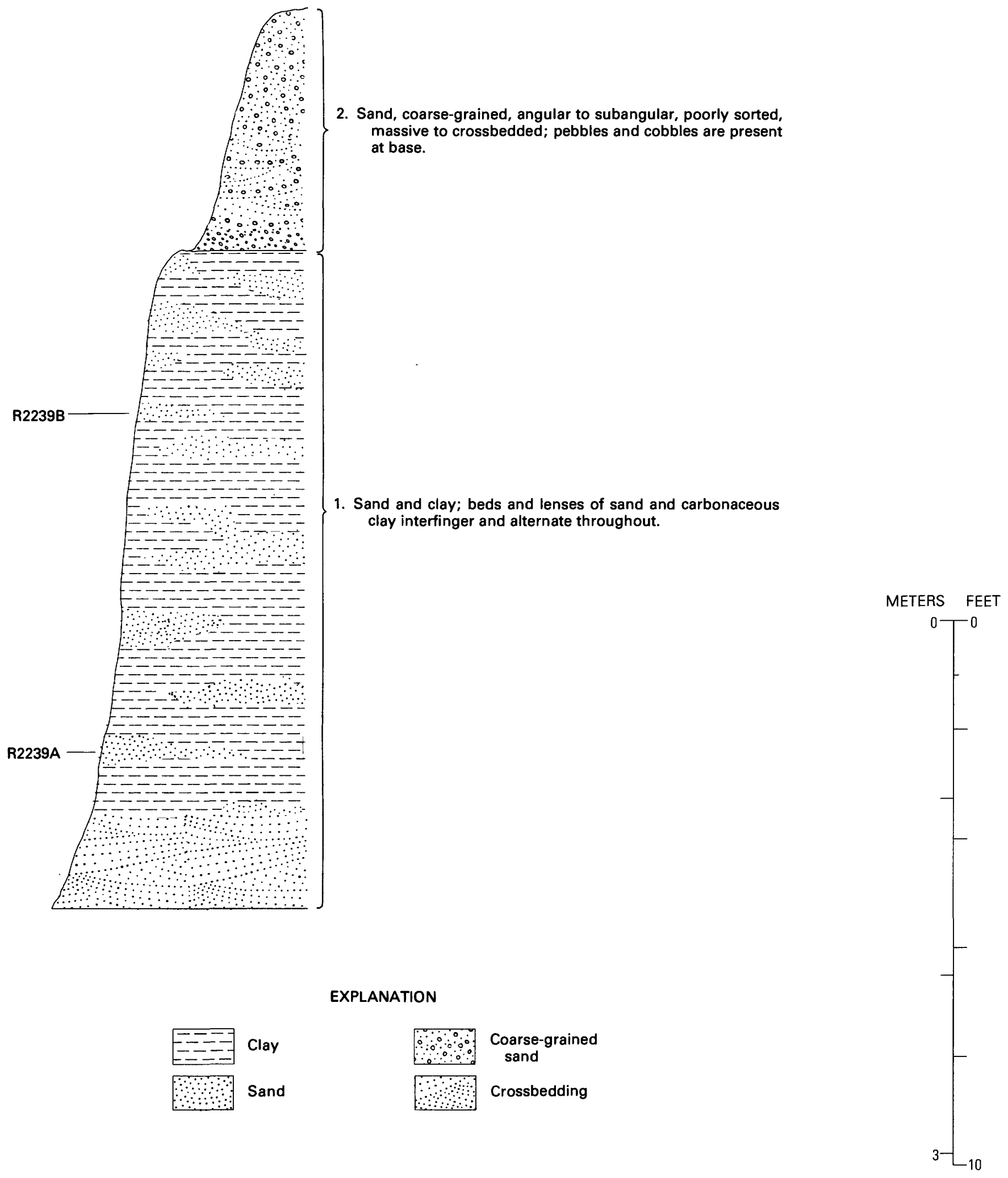

FIgURE 6. -Stratigraphic column of the section exposed at Jessups Landing. U.S. Geological Survey Paleobotanical Collection Numbers are to the left of the column. Lithologic unit numbers are to the right of the column. 
Landing, and four carbonaceous clay samples were taken for palynologic analysis. The stratigraphic positions of the samples are indicated in figure 7. The occurrences of megafossils from these collections are presented in table 2, and the biostratigraphically important pollen species recovered from the carbonaceous clays are listed in table 3 , along with the relative frequency of dinoflagellates and acritarchs.

\section{DISCUSSION}

The megafossil assemblage from samples 31796 and 31868 of unit 2 appears to have been transported, mixed, and significantly biased by preservational (diagenetic) factors. As preserved, the molluscan ele- ments are almost entirely epifaunal suspension feeders. The most unusual aspect of these collections, however, is the abundance of bryozoa and barnacle plates. The bryozoans occur as encrusters on shells and as broken portions of branching types. Gooseneck barnacles are of occasional to common occurrence in the Gulf Coast and Western Interior chalks but have not been reported in as high an abundance from quartzose clastic sediments as we have observed them in these samples.

The megafossil assemblage of sample 31795 (unit 3) has also been transported; it contains elements of bar, lower shoreface, and possibly grass-flat facies. The absence of deposit feeders reflects firm, sandy bottom conditions lacking in organic content. No marginal marine elements are present in this sample, and the
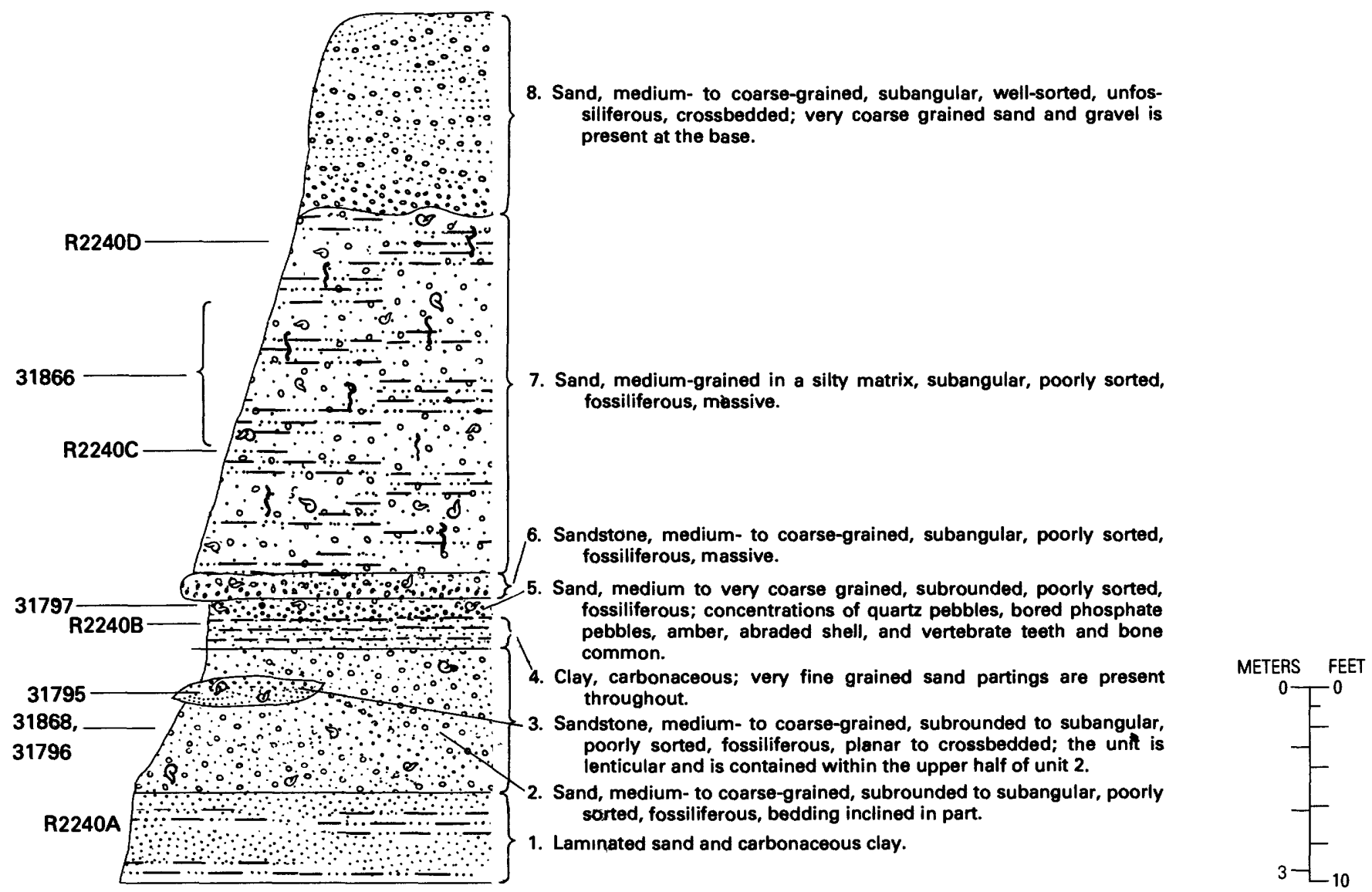

EXPLANATION
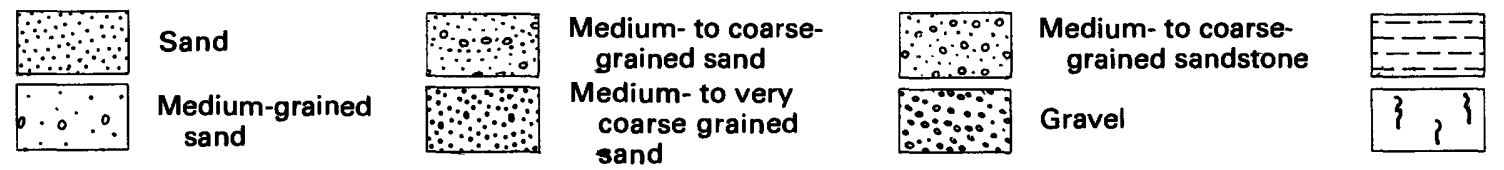

Clay

Burrows

FiguRE 7.-Stratigraphic column of the section exposed at Donoho Creek Landing. U.S. Geological Survey Mesozoic Invertebrate Collection Numbers are to the far left and U.S. Geological Survey Paleobotanical Collection Numbers are to the near left of the column. Lithologic unit numbers are to the right of the column. 
assemblage in general suggests nearshore, open marine conditions of normal salinity. The presence of only one barnacle plate in this sample, compared to the abundance of plates in the surrounding sands of unit 2, suggests a short-term increase in energy regime during deposition of unit 3; this conclusion is supported by the larger shell size in unit 3 than is found in unit 2.

\section{Robinsons Landing \\ STRATIGRAPHIC COLUMN}

Here, as at Donoho Creek Landing, approximately 30 $\mathrm{ft}$ of Cretaceous sediments are exposed. Three lithologic units are recognized within the Cretaceous deposits (units 1-3 of fig. 8), overlain by $10 \mathrm{ft}$ of alluvial(?) sediments (unit 5 of fig 8). Between the Cretaceous and alluvial(?) sediments are discontinuous lenses of shell, marl, and bored nodules (unit 5 of fig. 8) that probably belong to the Waccamaw Formation.

\section{PALEONTOLOGY}

At Robinsons Landing, four megafossil collections were made, and palynologic samples were taken at three horizons; the stratigraphic positions of these samples are shown in figure 8, and the megafossil and biostratigraphically important palynomorphs recovered from them are listed in tables 2 and 3, respectively. Dinoflagellate and acritarch abundance is also presented in table 3.

\section{Browns Landing}

STRATIGRAPHIC COLUMN

At several places over a reach of about $150 \mathrm{yd}$ along the river in the vicinity of Browns Landing, sandstone blocks litter the banks but the bluffs are overgrown with vegetation. At one point (milepost 49.2), we were able to recover a partial section by digging into a covered but near-vertical face. Three lithologic units within the Cretaceous were recognized (units 1-3 of fig. 9 ), but both the base and the top of the section were obscured by vegetation.

\section{PALEONTOLOGY}

Two collections of megafossils were made at Browns Landing. The stratigraphic positions of these samples are shown in figure 9, and the megafossils are listed in table 2. Similarly, two palynomorph samples were taken at Browns Landing; assemblages of the biostratigraphically important species are listed in table 3, along with the relative abundance of dinoflagellates and acritarchs. The stratigraphic positions of the palynomorph samples are shown in figure 9.
DISCUSSION

The restricted nature of the outcrop precludes lateral tracing of the units. The intermittent distribution of the sandstone float blocks of unit 1 along the river most probably indicates a lensing unit.

\section{REMARKS}

Similar lithostratigraphic units are exposed at Donoho Creek, Robinsons, and Browns Landings. The lan rated sand and clay sequence at the base of the sf in at Robinsons Landing (unit 1 of fig. 8) appears to be the same stratigraphic unit as the basal unit of Donoho Creek Landing (unit 1 of fig. 7). This unit, if present at Browns Landing, is covered. The sands of units 2 and 3 at Donoho Creek Landing are absent at Robinsons Landing but present (units 1 and 2) at Browns Landing, which suggests rapid lateral facies changes at this stratigraphic horizon.

The Cretaceous units that overlie these variable lithologies show a greater lateral consistency throughout these sections. Present at all three sections is a thin (2-in-thick) zone of poorly sorted, relatively coarsegrained sand that contains phosphate pebbles and grains, shark teeth, vertebrate remains, rip-up clasts, and other evidence that an unconformity occurs at the base of the unit (that is, at the bases of unit 5 at Donoho Creek Landing, unit 2 at Robinsons Landing, and unit 2 at Browns Landing). The stratigraphically highest Cretaceous unit at all three sections (units 7, 3, and 3 of Donoho Creek, Robinsons, and Browns Landings, respectively) is also laterally persistent, as shown by its uniform lithologic character and contained fauna. Hence, the unconformity recognized at these localities separates lithologic units indicative of rapidly changing facies and energy conditions below from units indicative of more uniform conditions above.

\section{INTERPRETATIONS \\ Age and Biostratigraphic Correlations}

Previous interpretations regarding the nature of the Black Creek-Peedee contact were based, in large part, on the ages assigned to the sections from Walkers Bluff to Browns Landing. The megafossil data provided by Stephenson (1923) and the megafossil and microfossil data provided by Brett and Wheeler (1961) were used by them and subsequent investigators as evidence that the Walkers Bluff to Browns Landing sections are synchronous or, at most, were deposited during an immeasurably short time span.

The previously suggested synchroneity is based primarily on similarities in the fauna reported from Walkers Bluff and Donoho Creek Landing. However, 

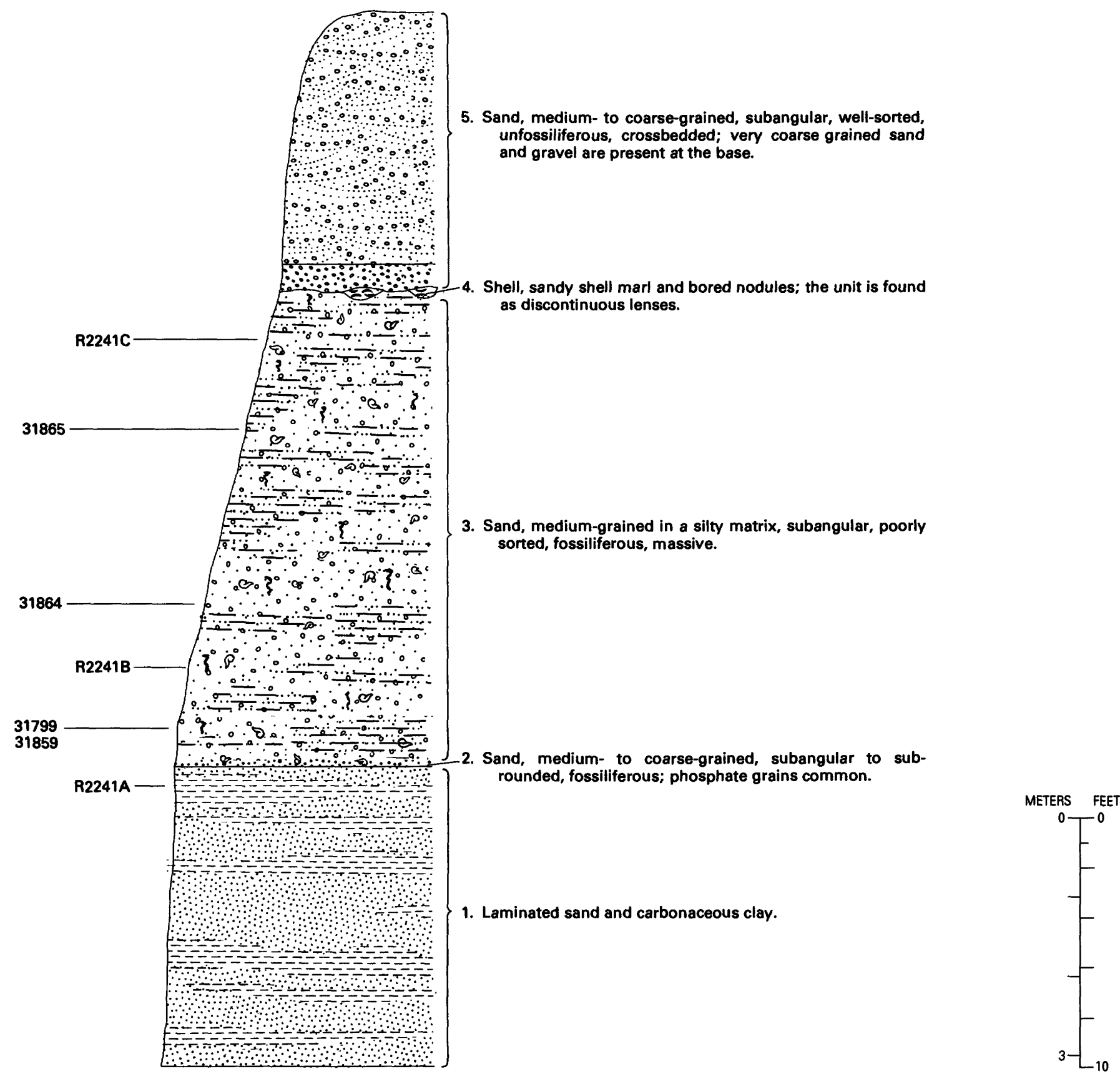

EXPLANATION

\begin{tabular}{|c|c|c|c|}
\hline आ! & Sand & 高 & Grave \\
\hline & $\begin{array}{l}\text { Medium-grained } \\
\text { sand }\end{array}$ & $\begin{array}{l}E=z=-1 \\
E=2=-1\end{array}$ & She \\
\hline$\because \because$ & $\begin{array}{l}\text { Medium- to coarse- } \\
\text { grained sand }\end{array}$ & & \\
\hline
\end{tabular}

FIGURE 8.-Stratigraphic column of the section exposed at Robinsons Landing. U.S. Geological Survey Mesozoic Invertebrate Collection Numbers are to the far left and U.S. Geological Survey Paleobotanical Collection Numbers are to the near left of the column. Lithologic unit numbers are to the right of the column. 


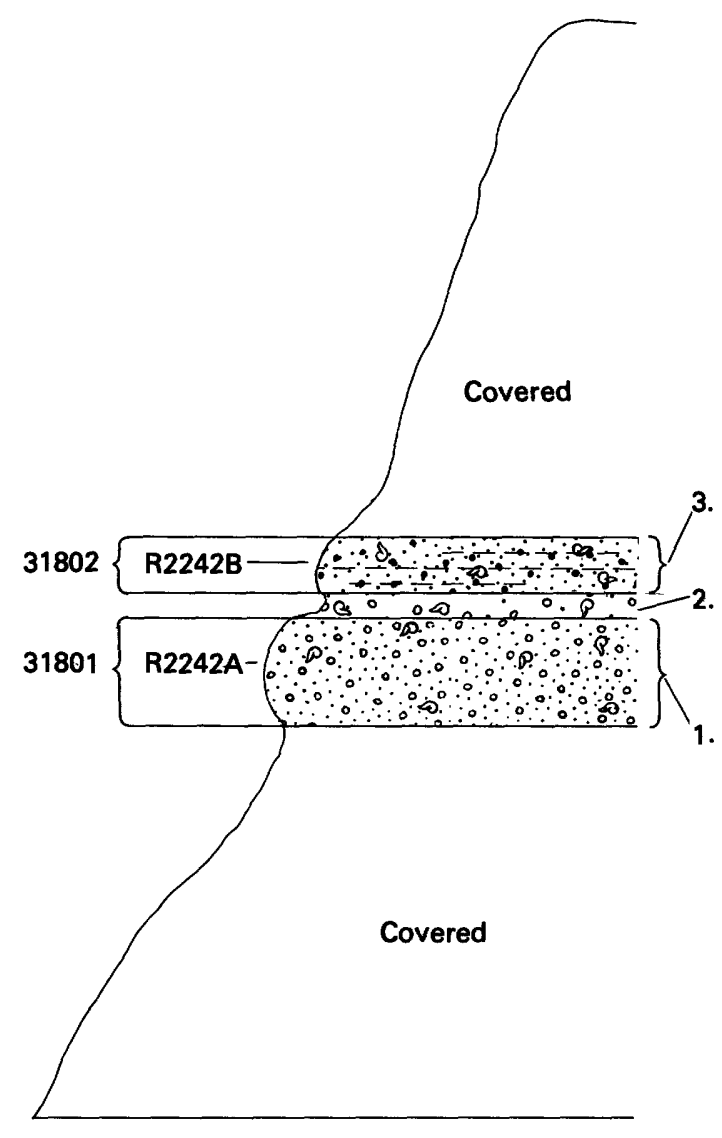

3. Sandstone, fine-grained to granule-sized, subangular, poorly sorted, fossiliferous, bedding characteristics not observed.

2. Sand, fine- to medium-grained, subrounded to subangular, poorly sorted, fossiliferous; phosphate grains and pebbles, vertebrate remains, and abraded shell material are present.

1. Sandstone, medium- to coarse-grained, subrounded to subangular, fossiliferous; bedding is planar to inclined.

\section{EXPLANATION}
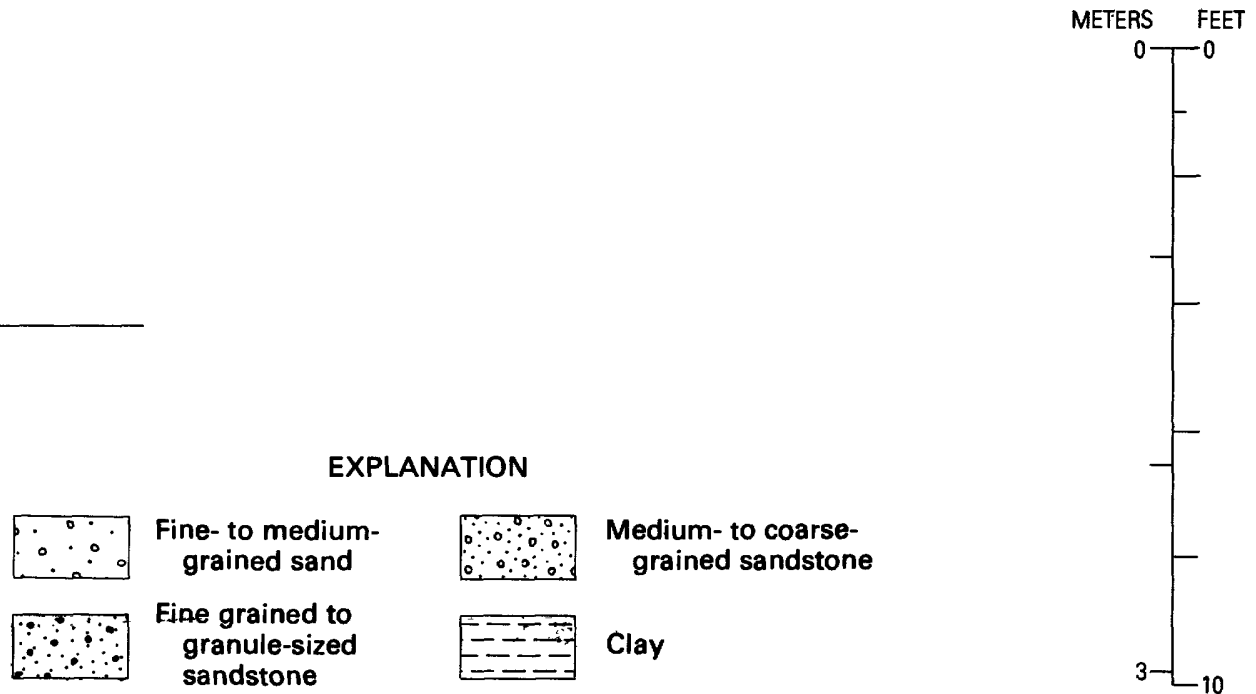

FIGURE 9.-Stratigraphic column of the section exposed at Browns Landing. U.S. Geological Survey Mesozoic Invertebrate Collection Numbers are to the far left and U.S. Geological Survey Paleobotanical Collection Numbers are to the near left of the column. Lithologic unit numbers are to the right of the column.

two problems that exist in the reporting of the paleontologic data from these localities suggest the similarities may be more apparent than real. First, the faunal lists presented by Stephenson $(1912,1923)$ from Donoho Creek Landing are composites; he did not distinguish the levels from which the fossils were collected. Therefore, any changes in fauna that may occur within the sections are masked. Second, the fauna reported by Stephenson (1923) and Brett and Wheeler (1961) from Walkers Bluff was derived from a sandstone that these and other workers (for example, Heron and Wheeler, 1964) considered as capping the Cretaceous section at this locality. No counterpart of the blocks is exposed in any of the sections at Walkers Bluff.
With regard to the sandstone from which the Walkers Bluff fauna was collected by Stephenson $(1912,1923)$ and Brett and Wheeler (1961), a comparison of our measured sections with those provided by Stephenson $(1912,1923)$, Brett and Wheeler (1961), and Heron and Wheeler (1964) indicates that the sandstone considered by these workers as capping the Cretaceous part of the section equates with the zone of sandstone blocks of Cretaceous age that we consider to have been reworked into the base of the Waccamaw Formation (see figs. 2 and 3). Evidence that these blocks of sandstone are not stratigraphically in place but are, in fact, reworked is as follows:

1. Many of the blocks are underlain by a few inches of 
shell marl of the Waccamaw Formation. As mentioned in our description of the upstream and medial sections at Walkers Bluff, the shell marl that immediately underlies the blocks of sandstone contains phosphate pebbles, clay balls, and wood fragments, all of which indicate the presence of an unconformity below the sandstone blocks.

2. Both the upper and lower surfaces of the blocks show round-based, cylindrical (pholad?) borings that commonly are more than $1 \mathrm{in}$. long; the apertures of the borings are worn.

3. Several of the blocks we examined were encrusted on all sides by Tertiary pyncnodonts, barnacles, and colonial corals (shell material preserved) and Spondylus (shell material permineralized). The contrast between mineralized and original shell material suggests more than one episode of epizoan encrustation. In addition, barnacles, bryozoa, and other debris are cemented in patches on both the upper and lower surfaces.

4. The fauna contained within the blocks, although of Cretaceous age, is distinct from the fauna of any of the other collections made at Walkers Bluff (see table 2).

These features indicate that the sandstone blocks have had a long and complex history that may predate their incorporation in the Waccamaw Formation. The presence of broken and worn shell, plant, and bone debris and nonarticulated bivalves together with clay casts within the sandstone suggests that the contained fauna was transported. Yet many of the bivalves are well preserved, indicating that they were derived from nearby localities. Subsequent to lithification, the blocks were exposed and bored. The blocks were then transported, during which time the apertures of the borings were eroded. At some later time, the sandstone blocks acted as a hardground attachment surface for epizoans, some of which overgrew the worn margins of the borings. Because the encrusters are present on both the upper and lower surfaces, it appears that the blocks again had been transported and (or) rolled at least once prior to their incorporation in the Waccamaw Formation.

Regardless of their postdepositional history, the reworked nature of the sandstone blocks in the upper part of the Walkers Bluff section suggests that neither their stratigraphic position nor the contained fauna should be considered in any interpretation of the age of the section or in any physical correlation of the Cretaceous lithologic units exposed at Walkers Bluff with those at other localities. Therefore, the age of the in-place Cretaceous deposits at Walkers Bluff should be based only on an assessment of the in-place invertebrate fauna from samples $31844,31849,31843,31850,31845,31847$, and 31848 , and the palynomorph samples R2238A, B, $\mathrm{C}$, and $\mathrm{D}$.

The age of the sediments from the Cape Fear River sections as suggested by the invertebrate fauna can best be established by relating the fauna to the zonation established by Stephenson $(1914,1923)$ for the Upper Cretaceous Series of the Coastal Plain province. According to this zonation, two range zones are recognized in the Campanian and Maestrichtian Stages: the Exogyra ponderosa Zone below and the $E$. costata Zone above. A third zone, the $E$. cancellata Zone, is defined by the range of the nominate species and includes the lower part of the $E$. costata Zone. The zones and the ages assigned to them are shown in the top half of figure 10. In the bottom half of figure 10 are the ranges of several species of mollusks that Stephenson (1914, 1923), Sohl and Mello (1970), and Sohl and Smith (1980) have shown to be biostratigraphically useful and that are present in our collections from the Cape Fear River sections.

A comparison of the distribution of invertebrate fossils in the Walkers Bluff to Browns Landing sections (table 2) with the ranges indicated in figure 10 suggests the following:

1. The in-place Cretaceous sediments at Walkers Bluff can be placed high in the Exogyra ponderosa Zone but not at the top of the zone. This is suggested by the concurrence of Haustator quadrilira, Phacoides? glebula, and Flemingostrea subspatulata (early form).

2. At Deepwater Point, the concurrence of Phacoides? glebula and Flemingostrea subspatulata (early form) suggests that the sediments there, too, can be placed near, but not at, the top of the Exogyra ponderosa Zone. The first occurrence of Crenella mitchelli and the apparent absence of Haustator quadrilira further suggests that the sediments at Deepwater Point may be younger than those exposed at Walkers Bluff.

3. The basal units that occur below the unconformity at Donoho Creek Landing (units 1-4 of fig. 7) and Browns Landing (units 1 and 2 of fig. 9) include Exogyra ponderosa erraticostata, Flemingostrea pratti, and Exogyra costata spinosa. As shown in figure 10 , their concurrence suggests a biostratigraphic equivalency with the uppermost part of the Exogyra ponderosa Zone.

4. The uppermost Cretaceous units at Donoho Creek Landing (unit 7 of fig. 7), Robinsons Landing (unit 3 of fig. 8), and Browns Landing (unit 3 of fig 9) contain Exogyra ponderosa erraticostata, E. cancellata, $E$. costata spinosa, and Anomia tellinoides, which suggest that these units can be assigned to the basal part of the Exogyra cancellata Zone. 
5. The sandstone blocks incorporated in the base of the Waccamaw Formation at Walkers Bluff are faunally similar to the units at Deepwater Point and below the unconformity at Donoho Creek and Browns Landings. This similarity indicates that the blocks at Walkers Bluff were derived from a unit situated stratigraphically above any of the in-place Cretaceous units exposed in the bluff. In support of this conclusion is the presence of Flemingostrea pratti in both the reworked sandstone blocks at Walkers Bluff and the units below the unconformity at Donoho Creek and Browns Landings. The restricted stratigraphic range of this species (see fig. 10) indicates similar ages for the units in which it is contained, an age that is younger than that suggested by the fauna of the in-place Cretaceous units at Walkers Bluff.

According to the ages assigned to the invertebrate zone by Brouwers and Hazel (1978), the Walkers Bluff to Browns Landing sections are latest Campanian to earliest Maestrichtian in age and are not synchronous but chronologically sequential.

Our palynologic data indicate ages that are similar to, although less precise than, those suggested by the invertebrate data for the Cape Fear River sections between Walkers Bluff and Browns Landing. The less precise nature of the palynologic data is the result of several factors, among which are the limited geographic sampling upon which the existing zonation of Wolfe (1976) was based and the lack of taxonomic descriptions of the biostratigraphically important pollen types upon which the zonation was established.

Despite these drawbacks, however, broad similarities do exist between the Cape Fear River sections and the Raritan and Salisbury embayments of the northern Atlantic Coastal Plain with regard to the stratigraphic distribution of certain pollen types. Figure 11 shows the ranges of the 31 biostratigraphically important pollen species present in the Walkers Bluff to Browns Landing sections (see table 3) as they occur at the

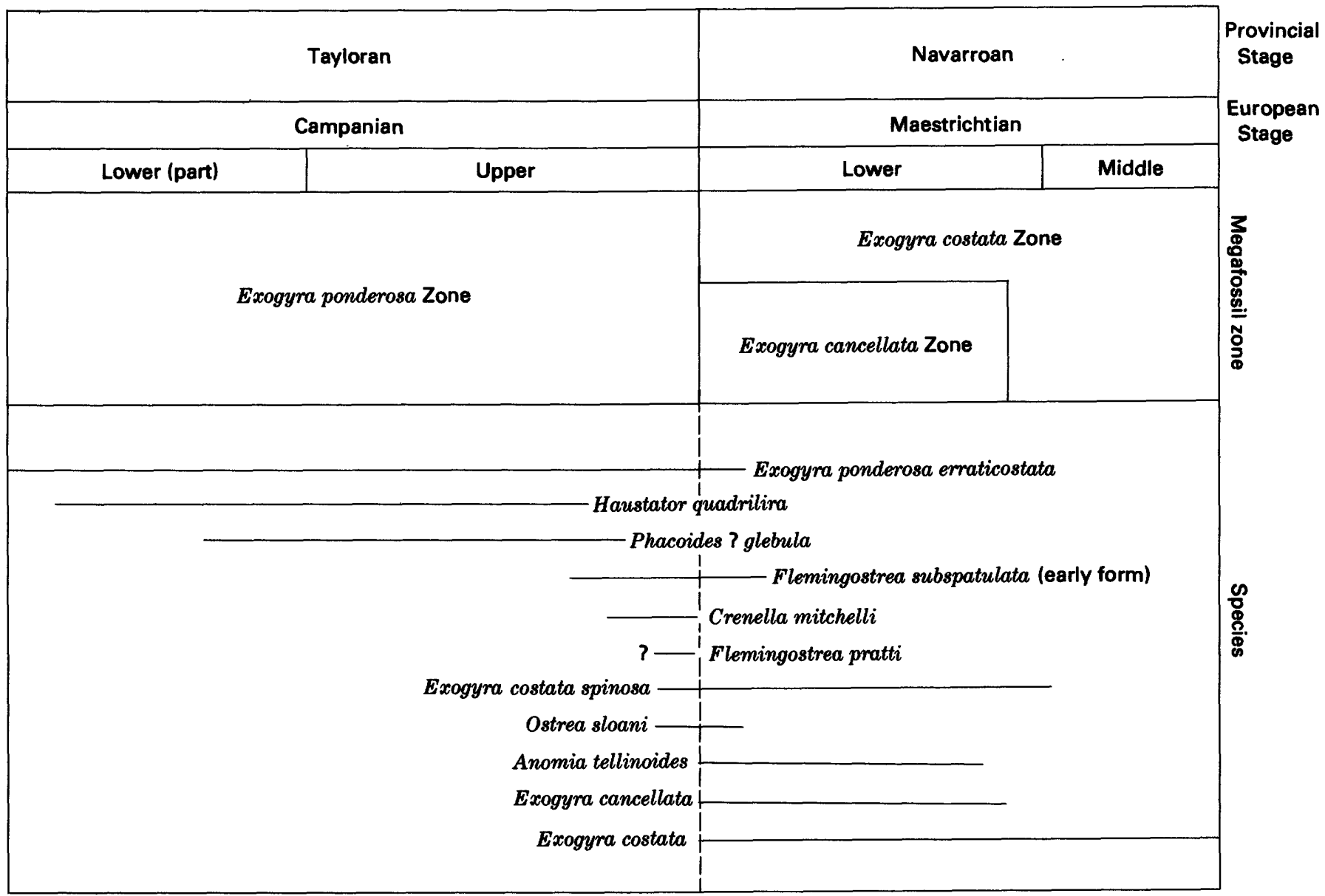

FIGURE 10.-Stratigraphic ranges of 11 biostratigraphically important invertebrate fossils that are found in exposures along the Cape Fear River between Walkers Bluff and Browns Landing. 


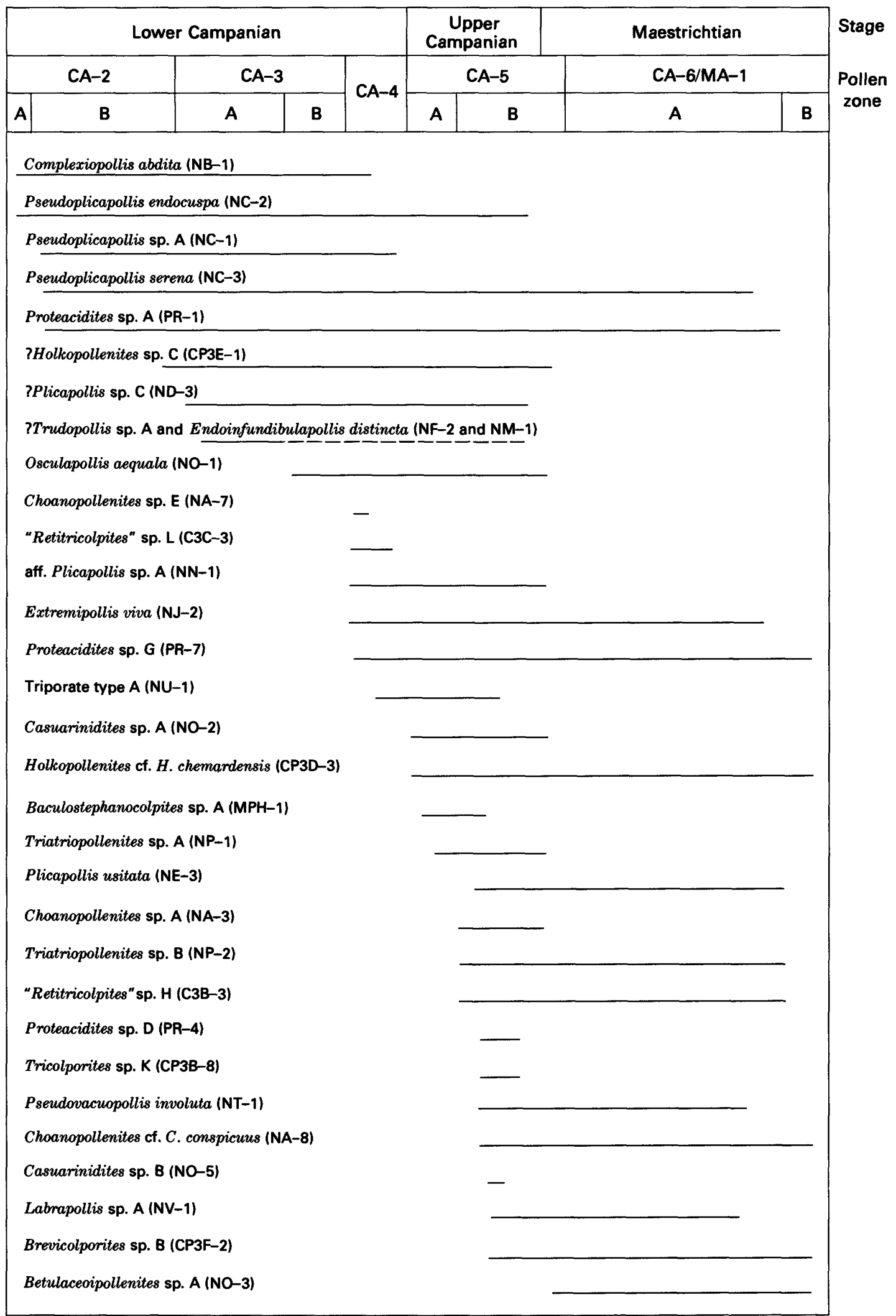

FIGURE 11.-Stratigraphic ranges of 31 biostratigraphically important pollen species that are found in exposures along the Cape Fear River between Walkers Bluff and Browns Landing (modified from Wolfe, 1976). The alphanumeric code assigned by Wolfe to each species is in parentheses after the binomen. 
stratotypes of Wolfe's (1976) zones; the figure gives the pollen zones established by Wolfe (1976) and the ages assigned to the Campanian and Maestrichtian lithostratigraphic units of the Raritan and Salisbury embayments by Brouwers and Hazel (1978).

A comparison of the data presented in table 3 and figure 11 provides useful information with regard to the application of Wolfe's (1976) zonation to the Campanian and Maestrichtian units of North Carolina. Specifically, it indicates that the ranges of some, if not all, of the guide palynomorphs must be modified. The need for extending the ranges of some species is indicated by the concurrence of species in the Cape Fear River samples that Wolfe (1976) indicated as being separated in time; most notable is the concurrence of Complexiopollis abdita, whose last occurrence upsection was recorded by Wolfe (1976) from zone CA-4, with Plicapollis usitata, Pseudovacuopollis involuta, and others whose first appearance upsection was reported from subzone CA-5B.

Despite the imprecise nature of the palynologic data, the Walkers Bluff to Browns Landing sections appear to be biostratigraphically situated somewhere between pollen zone CA-4 of early Campanian Age and subzone CA-5B of late Campanian to early Maestrichtian Age, a range that encompasses the ages suggested by the invertebrate data.

Some palynologic events within the sections under investigation suggest possible relationships between the invertebrate and the palynologic zonations. One of these events is the last occurrence upsection of Complexiopollis abdita in the units below the unconformity at Donoho Creek, Robinsons, and Browns Landings. This species, along with several other species of Complexiopollis, is present in every Cape Fear River sample examined below these beds, including that part of the section stratigraphically below Walkers Bluff. However, no representatives of the genus are present stratigraphically above their last recorded occurrence at Donoho Creek, Robinsons, and Browns Landings. Hence, the top of the range of the genus Complexiopollis may be a palynologic datum that corresponds to the top of the Exogyra ponderosa Zone. Similarly, Betulaceoipollenites sp. A first appears above the unconformity at the Donoho Creek-Robinsons-Browns Landings sections. The species is present in almost all samples stratigraphically above the unconformity, and apparently it ranges to the top of the Cretaceous System of the Cape Fear River region. Its range, therefore, appears to coincide with that of Exogyra costata.

In addition to suggesting possible ages for the Walkers Bluff to Browns Landing sections, both the faunal and palynomorph data can be used to correlate these sections with lithologic units in other areas of the
Coastal Plain province. The biostratigraphic correlations suggested by these data for the Upper Cretaceous Series of New Jersey and the Chattahoochee River region of Alabama and Georgia are shown in figure 12. The correlation of the Cape Fear River section with the Chattahoochee River section is based on similar stratigraphic distributions of megainvertebrate fossils in both areas. Paleontologic studies in New Jersey and the Chattahoochee River region have been extensive, and we are more confident in correlating the Cape Fear River section with these areas than with others.

If we are correct both in the ages assigned to the Cape Fear River sections and in the correlations indicated in figure 12, then two conclusions can be drawn regarding the unconformity that occurs at Donoho Creek, Robinsons, and Browns Landings. First, the unconformity is of limited duration, occurring sometime between late Exogyra ponderosa Zone time and early E. cancellata Zone time (that is, during the short time span of concurrence of $E$. ponderosa erraticostata and $E$. costata). Second, the unconformity is of limited geographic extent. Although we have not documented the presence of this unconformity in other areas of North and South Carolina, it appears to be geographically restricted thereto; it has not been recognized in either New Jersey or the Chattahoochee River region where sedimentation has apparently been continuous during the time represented by the unconformity in the Cape Fear River area.

\section{Paleoenvironmental Interpretations}

The stratigraphic, lithologic, and paleontologic data presented by us and by previous workers suggest that, in the Cape Fear River area, an abrupt paleoenvironmental change takes place across the unconformity present at the Donoho Creek-Robinsons-Browns Landings sections. Below the unconformity, the lithologic units represent rapidly changing nearshore environments, whereas a uniform, deeper water, open marine shelfal environment is suggested by the units above the unconformity.

As pointed out by Swift (1964) and Swift and Heron (1967), tidal-flat deposits are represented below the unconformity by the laminated sands and carbonaceous clays at the base of Walkers Bluff (unit 1 of figs. 2-4), Donoho Creek Landing (unit 1 of fig. 7), and Robinsons Landing (unit 1 of fig. 8). This environment, which is the most frequently observed of the environments stratigraphically below the unconformity, is characterized by planar bedding and localized minor crossbedding, the presence of glauconite in the sand-dominated facies, scattered burrow structures, and relatively fine grained and well sorted sediment. In addition, the 
environment is dominated by infaunal deposit and suspension feeders (sample 31844, downstream section at Walkers Bluff), which indicate a relatively stable and organically rich substrate; such assemblages are consistent with the interpretation that this is a tidal-flat environment.

In contrast to the laminated, horizontally bedded, and laterally persistent nature of the tidal-flat deposits described above, the abrupt lateral and vertical changes in the sands and clays exposed at Jessups Landing indicate an environment in which energy conditions fluctuated rapidly. There, the sands are coarser grained and entirely crossbedded; clay drapes along the bedding planes attest to rapidly changing energy conditions. These characteristics, coupled with the presence of Ophiomorpha burrows, suggest a nearshore to upper shore-face depositional environment for the sands at Jessups Landing. These sands alternate and interfinger with discontinuous, laminated, carbonaceous clay beds that contain fine-grained sand partings. The clays were deposited under relatively uniform lowenergy conditions, and the entire Jessups Landing section probably represents a sequence of oscillating near- shore or, as suggested by Powers (1951), fluvially dominated depositional environments.

The sand units at Walkers Bluff (units 2-4 of the upstream section, fig. 2; unit 2 of the medial section, fig. 3 ; unit 2 and the lenticular sandstones at the top of unit 1 of the downstream section, fig. 4) and below the unconformity at Donoho Creek Landing (units 2 and 3 of fig. 7) and Browns Landing (unit 1 of fig. 9) are highly variable in their sedimentary characteristics, faunal assemblages, and trophic structure nuclei. As we have already discussed, there is a rapid lateral facies change within the sand units above the tidal-flat deposits at Walkers Bluff from lower energy, more stable substrate environments at the downstream section to higher energy, less stable substrate environments at the upstream section. Similar rapid lateral facies changes are suggested for the sand units below the unconformity at Donoho Creek, Robinsons, and Browns Landings. Channel fills are indicated by the lithology, bedding characteristics, geometry, and preservational features of the fauna of unit 3 of Donoho Creek Landing and unit 1 of Browns Landing (see figs. 7, 9). These units are discontinuous, lenticular, and crossbedded

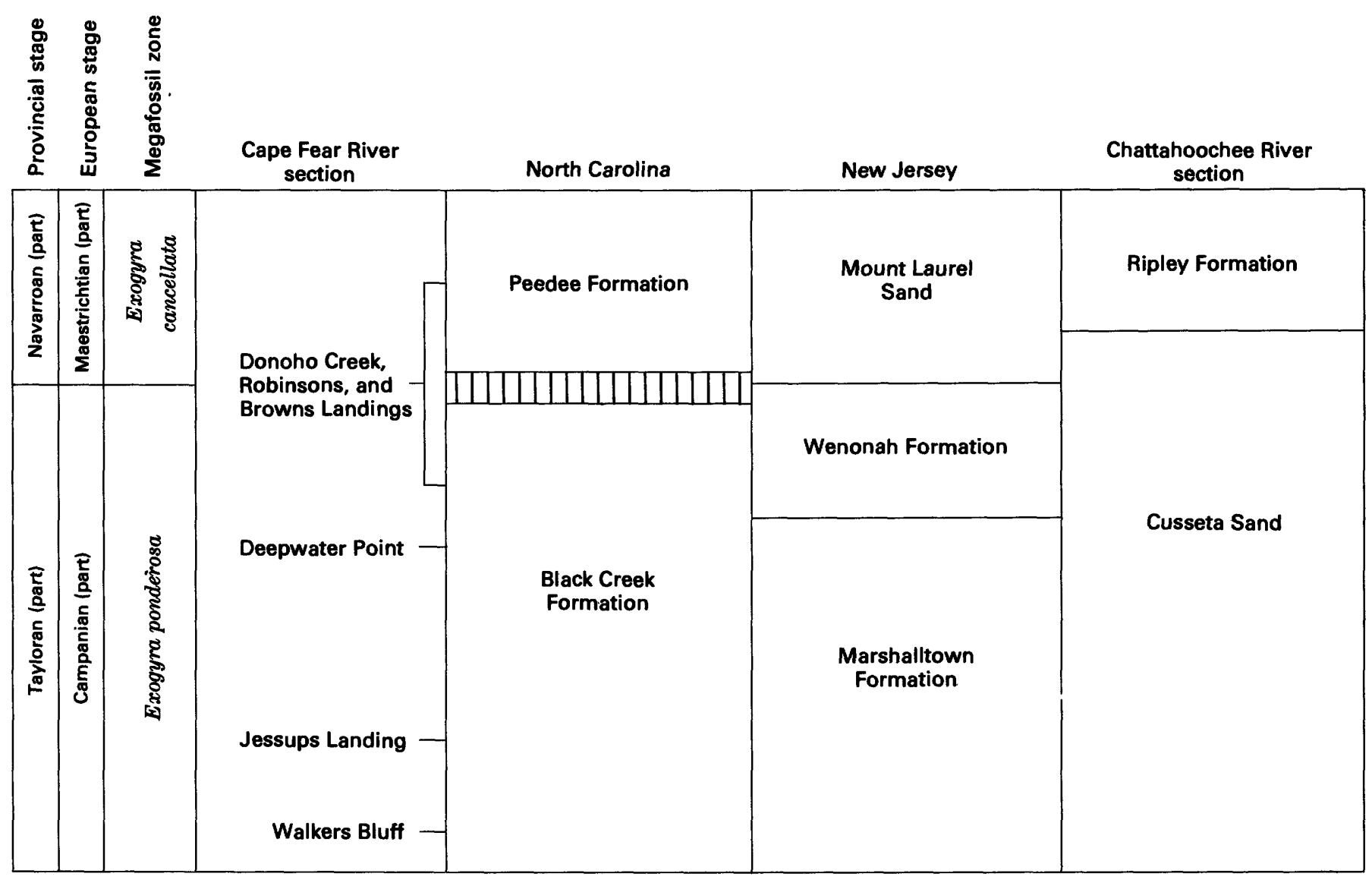

FIGURE 12.-Biostratigraphic correlation chart of the outcropping Cretaceous sections between Walkers Bluff and Browns Landing, Cape Fear River, N.C., and the sections of New Jersey and the Chattahoochee River, Ala. and Ga. 
and contain phosphate pebbles and wood fragments; zones of whole shell alternate with zones of fragmented shell material, but overall clast size fines upward. These lenticular channel fills are entirely contained within other sand units (unit 2 at Donoho Creek Landing, fig. 7), which are themselves discontinuous, as evidenced by their absence at Robinsons Landing. The discontinuous nature, poor sorting, fragmented shell material, abundant barnacle plates, and domination by epifaunal suspension feeders of the contained fauna all indicate relatively high energy, nearshore environments for these confining sand bodies.

Although we were unable to observe the geometry of and sedimentary structures within the sandstones that crop out in the channel of the Cape Fear River at Deepwater Point (sample 31860), their contained fauna suggest a depositional environment similar to that of the channel fill sands at Donoho Creek and Browns Landings. The assemblages are taxonomically similar, and both contain large shells and abundant barnacle plates.

The sandstone blocks that have been reworked into the basal part of the Waccamaw Formation at Walkers Bluff are also indicative of nearshore, high-energy conditions. Included in the poorly sorted, coarse-grained matrix of these blocks are clay clasts, worn bone, pieces of wood, broken and worn shell debris, and disarticulated but well-preserved shells that suggest a transported assemblage derived from nearby sources. In addition, the large number of taxodont bivalves (Postligata, Arca, Trigonarca), cardiids, ostreids (Exogyra, Flemingostrea), and intertidal neritid gastropods suggests a mixed community structure. Of particular paleoenvironmental importance is the presence of a vivipariid and a possible melanatriid snail in these sandstones, as they indicate that deposition occurred in proximity to fresh water, possibly a river mouth.

In contrast to the rapidly changing nearshore environments discussed above, the Cretaceous units above the unconformity at Donoho Creek Landing (unit 7 of fig. 7), Robinsons Landing (unit 3 of fig. 8), and Browns Landing (unit 3 of fig. 9) suggest a deeper water, open marine shelfal depositional environment. These units are massive and highly bioturbated and contain glauconitic quartz sands in a silty clay matrix. Faunally, they are dissimilar to the fossiliferous sands below, in that venerid bivalves are common, arcoids and cardiids are rare, and oysters dominate assemblages from the upper units, as opposed to the dominance of arcoids and tellinids in assemblages from the sands below. Where the assemblage is well preserved and thus more diverse, as in unit 3 of Browns Landing (fig. 9), it is dominated by infaunal filter-feeding bivalves. The infauna includes bivalved specimens of deep-burrowing filter feeders such as Panopea; it shows no trace of sig- nificant transport. Paleoenvironmentally, the assemblages from the upper, muddy sands at Donoho Creek, Robinsons, and Browns Landings are typical of open marine shelfal deposits that were deposited below wave base. Brett and Wheeler (1961) suggested that these upper units were deposited in an inlet seaward of a barrier ridge and in water depths of 20 to $30 \mathrm{ft}$. Although it is difficult to decipher Swift's (1964) paleoenvironmental interpretations of the lithologic units exposed at Donoho Creek, Robinsons, and Browns Landings, it appears that he agreed with the interpretations of Brett and Wheeler (1961). However, neither the sedimentary structures within these units nor their contained fauna support such conclusions.

Situated between the shallow-water, nearshore, highenergy deposits below and the dark, massive, muddy, shelfal deposits above, and immediately above the unconformity at Donoho Creek, Robinsons, and Browns Landings, is a thin (2-in-thick) zone of coarse-grained sand (unit 5 of fig. 7; unit 2 of fig. 8 ; unit 2 of fig. 9) that represents a condensed zone of some time significance. Included in this zone are concentrations of phosphate, vertebrate remains, shark teeth, and clay clasts that had accumulated on the upper surfaces of the underlying units during the time of nondeposition represented by the unconformity. Such concentrations have been widely recognized throughout the Coastal Plain province as evidence of an unconformity (Stephenson, 1929, and many subsequent workers). The faunal assemblage of this zone (samples $31797,31799,31859$; table 2) is similar to those of the units below and distinct from the assemblages in the units above, as the fossils were reworked into the zone from the unit below.

To support our contention that a significant paleoenvironmental change takes place at the unconformity at Donoho Creek, Robinsons, and Browns Landings, we plotted the relative abundance of dinoflagellates and acritarchs in the palynologic samples examined from the sections under consideration. These data are presented in figure 13. In samples from below the unconformity, the percentage of dinoflagellates and acritarchs ranges from 10 to 40 percent and averages 25.3 percent. However, the percentage of these organisms increases dramatically in samples from above the unconformity, in which the relative frequency is more than double that in the samples below. Such a drastic change in abundance of dinoflagellates and acritarchs is further evidence that a major paleoenvironmental change takes place at the unconformity, from nearshore environments below to open shelfal environments above.

\section{Physical Stratigraphy}

If we are correct in asserting that the exposures between Walkers Bluff and the Donoho Creek-Robin- 

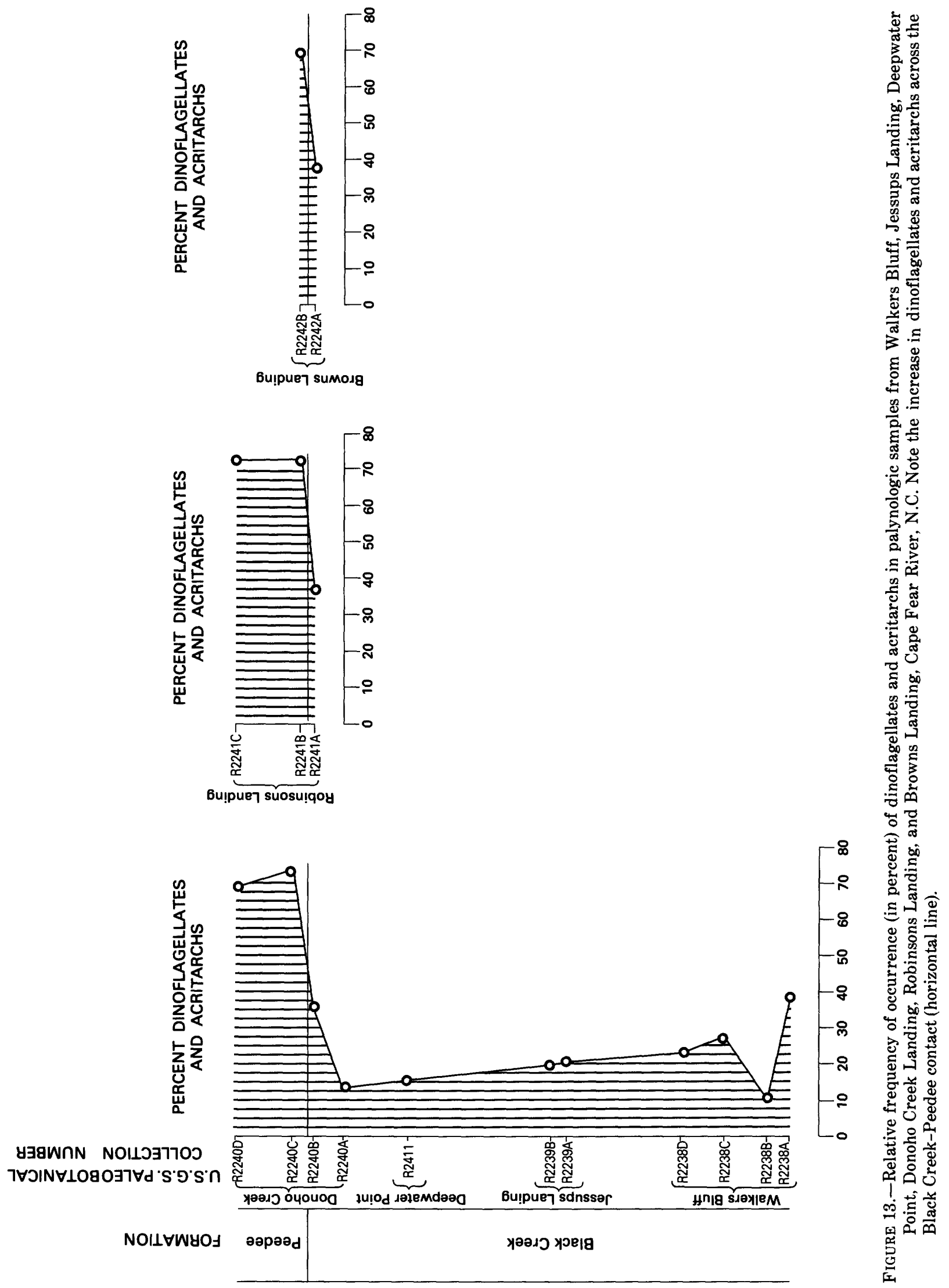
sons-Browns Landings sections are chronologically sequential and that a significant paleoenvironmental change takes place across the unconformity present at the downstream localities, then the stratigraphic relationships among the lithologic units exposed at these localities can be interpreted.

With regard to the lithologic units stratigraphically below the unconformity, two lines of evidence suggest that any attempt to physically correlate any of these units from one exposure to another is futile. First, the paleontologic data indicate that the sediments at each locality were deposited at slightly different times. (In this regard, we consider the exposures at Donoho Creek, Robinsons, and Browns Landings to be one locality divided into three sections.) Secondly, because many of these units lack lateral consistency within a single exposure, it is improbable that any single unit would maintain its lithologic characteristics from one locality to the next. Even the most persistent of these units, the laminated sands and clays of tidal-flat origin, are intercalated with the less persistent sand units and are themselves chronologically repetitive. The laminated sands and clays at Walkers Bluff are directly overlain by less persistent sand units, and similar laminated sands and clays at Donoho Creek, Robinsons, and Browns Landings are apparently underlain by the sandstones and marls at Deepwater Point and those that Stephenson $(1912,1923)$ reported at Jessups Landing.

The lithologic and faunal characteristics of the shelfal sands above the unconformity, however, are consistent for the sections within which they occur and are distinct from those of the units below the unconformity. The lithologic units at Walkers Bluff, Jessups Landing, Deepwater Point, and the Donoho Creek Landing to Browns Landing sections below the unconformity do not show the massive bedding, high degree of bioturbation, and silty clay matrix that is characteristic of these shelfal sands, nor do they contain the same shelfal fauna. Hence, no evidence exists for correlating the shelfal sands of Donoho Creek, Robinsons, and Browns Landings with any lithologic unit upstream (downsection).

\section{CONCLUSIONS}

The ages, paleoenvironmental interpretations, and stratigraphic relationships discussed above lead us to conclude that the contact between the Black Creek and Peedee Formations is disconformable in the Cape Fear River region. The disconformity is present at Donoho Creek, Robinsons, and Browns Landings; it separates high-energy, rapidly changing, nearshore environments of the Black Creek Formation below from open marine, shelfal environments of the Peedee Formation above.
Our conclusion that the Black Creek-Peedee contact is disconformable is in agreement with that of Brett and Wheeler (1961). However, their suggestion that the disconformity can be recognized for several miles along the Cape Fear River is not substantiated by our findings, as their "basal Peedee sandstone" at Walkers Bluff is apparently a series of reworked blocks of Black Creek sandstones incorporated in the base of the Waccamaw Formation.

The conclusion reached by both Stephenson (1912, 1923) and Heron and Wheeler (1964) that the contact between the Black Creek and Peedee Formations is conformable is based not only on a misinterpretation of the stratigraphic position of these reworked sandstone blocks at the top of the Walkers Bluff section but on the assumption that the fauna at Donoho Creek Landing is uniformly distributed throughout the section. Our data indicate that two distinctly different faunas occur here that are separated by the Black Creek-Peedee disconformity.

Swift (1964) and Swift and others (1969) interpreted the contact between the Black Creek and Peedee Formations as a ravinement. If one accepts their definition of a ravinement as a condition where, in a "sedimentary sequence, marine sediments rest disconformably on the coastal plain sediments or on the eroded remnants of the marginal record" (Swift, 1964, p. 100), then the contact in the Donoho Creek-Robinsons-Browns Landings area is a ravinement. The basal reworked bed of the Peedee, which contains phosphate, bone, teeth, abraded fossils, and clasts of clay and sandstone reworked from the underlying beds, rests directly on a surface eroded into subjacent units of various lithologies that represent several marginal marine environments. Similar sequences have been described for Cretaceous deposits in other areas of the Coastal Plain, such as New Jersey (Owens and Sohl, 1969). The major difference between the "ravinement" unit exposed at Donoho Creek, Robinsons, and Browns Landings and similar sequences elsewhere is the thinness of the Cape Fear River unit, which indicates an exceptionally rapid episode of transgression. Elsewhere, such basal units may be several feet thick and show graded and fining-upward character; at Donoho Creek Landing to Browns Landing, the overlying massive shelfal sand lies sharply on the cannibalistic unit. In addition, we disagree with previous workers in their placement of the "ravinement." At Walkers Bluff, Swift (1964, fig. 62, col. 3) placed the ravinement at the base of the sandstone that is reworked into the Waccamaw Formation; thus it has no relationship to the "ravinement" at the downstream sections.

The conclusions we have drawn concerning the ages, depositional environments, and stratigraphic relationships among the Walkers Bluff to Browns Landing sections are diagrammatically shown in figure 14 . In 
this figure, the Black Creek Formation is characterized as deposits representing a series of nearshore marine environments that interfinger throughout the upper part of the formation. The Peedee Formation disconformably overlies the Black Creek and is represented by massive, bioturbated, muddy sands of an open marine shelfal environment. Superimposed on these units in figure 14 are the approximate stratigraphic positions of the exposures at Walkers Bluff, Jessups Landing, Deepwater Point, and Donoho Creek, Robinsons, and Browns Landings.

Our conclusion that the contact between the Black Creek and Peedee Formations is disconformable suggests that the Upper Cretaceous Series of North Carolina as exposed along the Cape Fear River may consist not of a single marine transgression, as suggested by Brett and Wheeler (1961), Heron and Wheeler (1964), Swift (1964), and others, but of at least two cycles of transgression and regression. This hypothesis is supported by the Santonian Age assigned to the Cape Fear Formation by Christopher and others (1979), which, when coupled with the widely recognized unconformity between the Cape Fear and Black Creek Formations (see Stephenson, 1923; Heron and Wheeler, 1964), suggests that the Upper Cretaceous Series as exposed along the Cape Fear arch consists of at least three transgressive-regressive cycles. Additional studies are needed to demonstrate the regional nature of these cycles and to determine if the Black Creek-Peedee contact described in this report represents shifting deltaic lobes or a coeval regional event.

\section{MEASURED SECTIONS}

Complete descriptions of the lithologic units exposed at the three measured sections at Walkers Bluff, Jessups Landing, Donoho Creek Landing, Robinsons Landing, and Browns Landing are presented below; they are intended to augment the brief descriptions that accompany the stratigraphic columns of figures 2-4 and 6-9.

Walkers Bluff, upstream section

Unit 1

Sand and laminated clay. The sands are gray to greenish gray; iron-staining occurs along some bedding planes. The clays are carbonaceous, medium to dark gray. The sands are quartzose; mica and glauconite are each present in amounts as large as 10 percent. Comminuted plant debris is disseminated throughout, and carbonaceous matter is concentrated along some bedding planes. The sands are very fine to fine grained, well sorted, and subangular. Obvious burrows are
Thickness Ft In $\begin{array}{ll}16 & 8\end{array}$ rare, but clay laminae are disrupted along bedding planes (bioturbated), and occasional Ophiomorpha and fine Chondrites-like burrows are present. Thallassinoid burrows are present in the upper $4 \mathrm{ft} 0$ in, and wood is scattered throughout the unit. The upper $4 \mathrm{ft} 0$ in is dominated by small-scale crossbedded sands; clay laminae are thin, but clay clasts occur along bedding planes. The next lower $3 \mathrm{ft} 0$ in is dominated by a "saltand-pepper" glauconitic sand, where clay-lined burrows are present but rare. The next lower $5 \mathrm{ft} 8$ in is more highly bioturbated but has more obvious planar bedding than is found in the upper part; sand still dominates over clay.

Unit 2

Sand, yellow-brown to tan. The unit is dominantly quartzose, but angular to subangular feldspar clasts are common. Finely disseminated carbonaceous matter is present throughout the unit, and a few thin (1-in-thick) carbonaceous clay lenses are present. The sands are medium to mainly coarse grained, subangular, and poorly sorted; quartz pebbles as much as 0.25 in. in diameter are common. Worn and fragmented wood, bone, and shell material is present throughout, but no burrows were observed. The unit is crossbedded; the crossbedding is more apparent (that is, more highly developed?) in the upper part of the unit than it is at the base. A single 2-in-thick carbonaceous clay was observed lining the base of a channel fill near the top of the unit. The basal contact is sharp and planar.

Unit 3

Sandstone, yellow-brown to tan. The sandstone consists almost entirely of quartz; glauconite is present in minor amounts. The sandstone is medium to coarse grained, angular to subrounded, and poorly sorted. Shell material occurs throughout, and abraded wood, bone fragments, and clay clasts are present at the base. No burrows were observed. The unit is crossbedded to massive. The basal contact is sharp but undulating; the undulation is caused by differential cementation of the sands of units 2 and 3.
Thickness

Ft In

3 0

20 


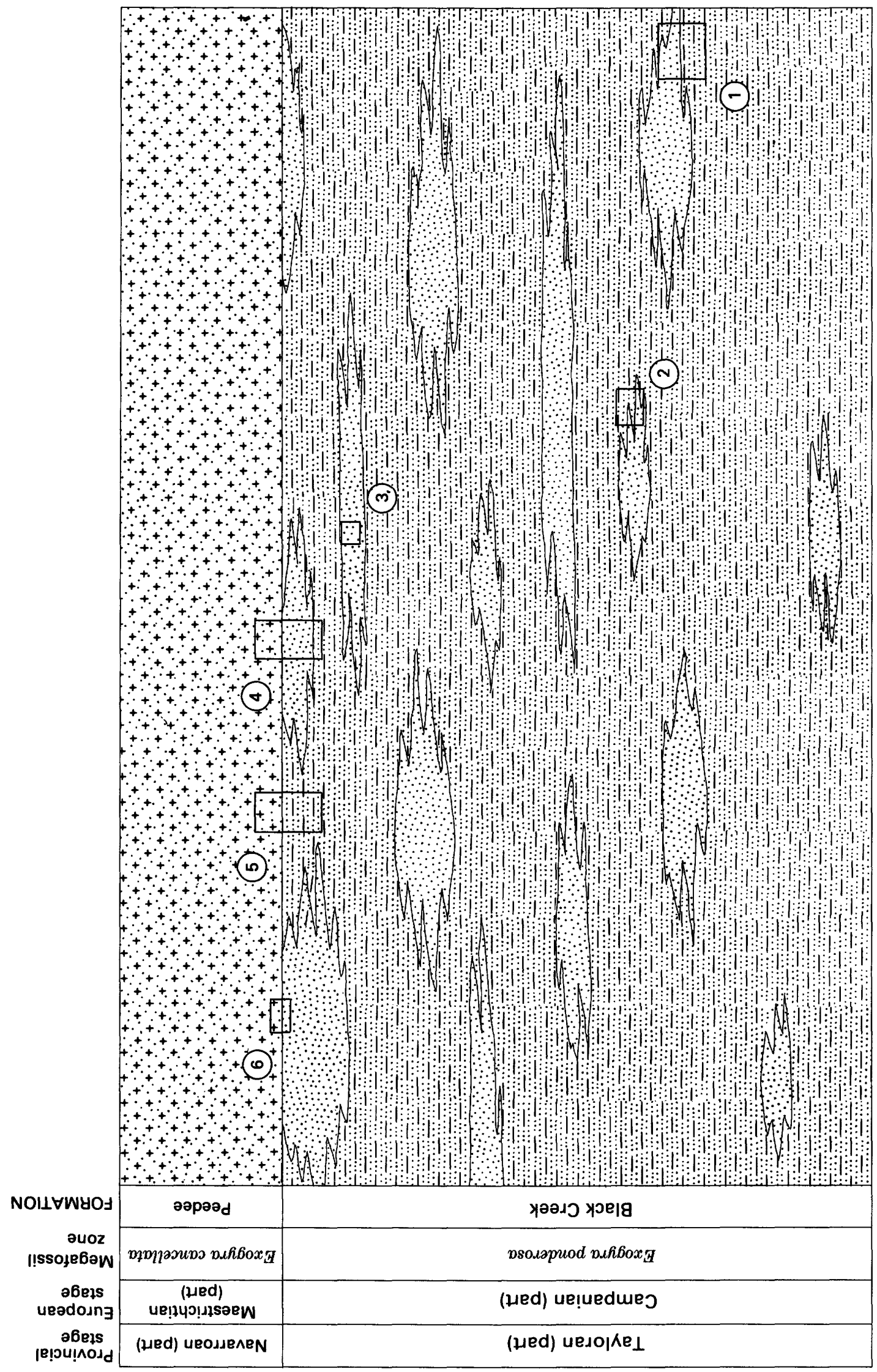


Unit 4

Sand, yellow-brown to tan. The unit is dominantly quartzose; glauconite is present in trace amounts. The sand is subangular, well sorted, and medium grained; no clay was observed as matrix, laminae, or lenses. The unit is unfossiliferous. The unit is massively bedded, and the basal contact is sharp and planar.

Unit 5

Laminated sand and clay. The clays are carbonaceous and dark gray to black; the sands are light gray but are commonly iron-stained yellow orange. The sands are quartzose, and mica and glauconite are present in minor amounts; comminuted plant material is disseminated throughout the sands. The sands are very fine to fine grained, subangular, and well sorted. No megafossils were observed. The upper $2 \mathrm{ft} 3$ in is dominated by sand, which occurs in beds as much as 3 in thick, and clay beds as much as 1 in thick. Clay beds thicken and clay is more abundant toward the base of the unit. The basal contact is sharp and planar.

Unit 6

Shell and sandy shell marl, buff to tan to yellow-brown. Shells are present as both whole and broken specimens. The marl consists of worn and weathered pieces of shell. The sand is quartzose; finely comminuted plant material occurs throughout the unit. The quartz sands are fine to medium grained, angular to subangular, and poorly sorted. Beds of whole shell, shell marl, and marly sand alternate throughout the unit; individual beds range in thickness from 1 in to $2 \mathrm{ft}$. The basal 1-2 $\mathrm{ft}$ of the unit contains phosphate pebbles, clay balls, and scattered, irregularly shaped sandstone blocks as much as $1 \mathrm{ft}$ in diameter. The basal 2-3 in of the unit contains carbonaceous material. The basal contact is sharp and irregular; pockets of shell debris. fill depressions cut into the underlying unit. Burrows as much as 4 in long extend down into the underlying unit and pipe down shell debris in a mushy, clayey, sand matrix.

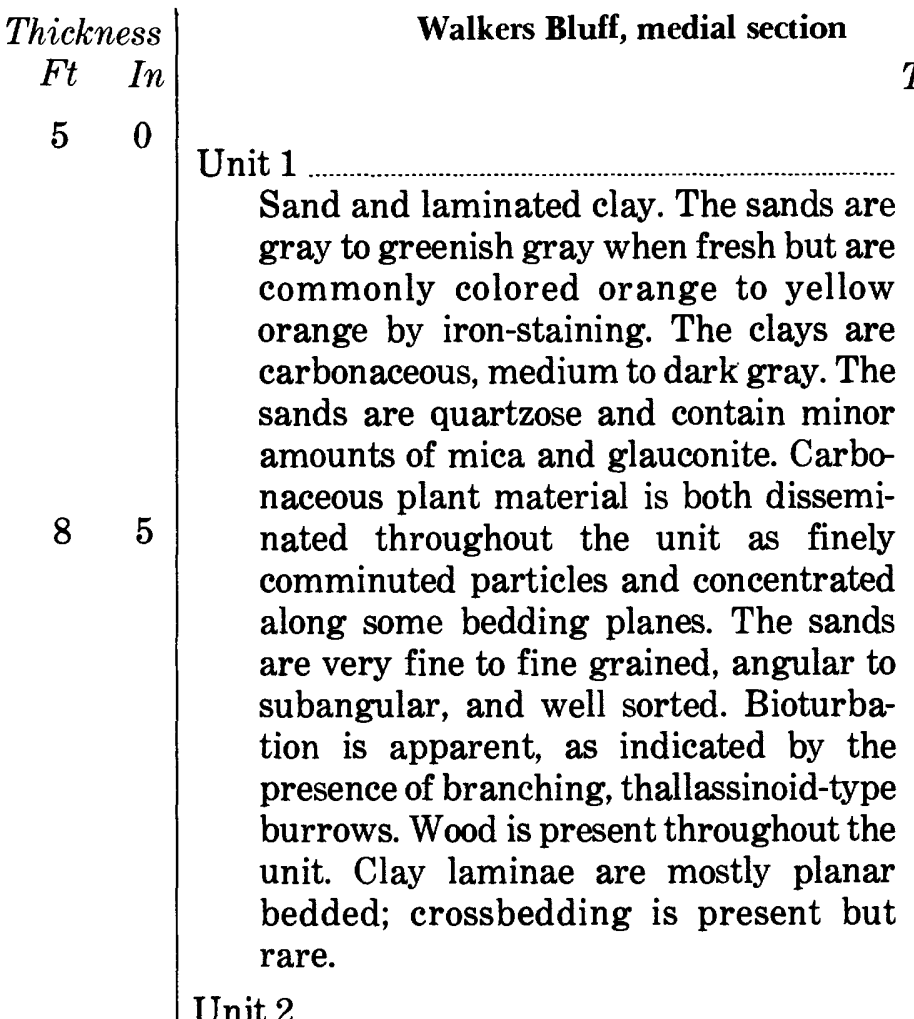

Sand, $\tan$ to yellow-brown. The unit consists almost entirely of quartz; finely comminuted plant material is distributed throughout. No mica or glauconite is present. The sands are fine grained, angular to subangular, and well sorted. The unit is fossiliferous and massively bedded. The basal contact is sharp and planar.

Unit 3

Laminated clay and sand. The clays are carbonaceous, dark gray to black; the sands are light gray to greenish gray but are commonly iron-stained orange to yellow orange. The sands are dominantly quartzose; mica and glauconite are present in minor amounts. The sands are very fine to fine grained, angular to subangular, and well sorted. No megafossils were observed. Clay dominates the unit, but the sand content increases toward the base. The basal contact is sharp and planar.

Unit 4

Shell and sandy shell marl, buff to tan to 20

\begin{tabular}{cr}
\multicolumn{3}{c}{ Thickness } \\
Ft & In \\
31 & 0
\end{tabular}

3

0

8

0

yellow-brown. Shells occur as both whole and fragmented specimens. The marl consists primarily of worn, weathered, and finely divided shell material. The sands are quartzose. Finely comminuted 


\section{Thickness
Ft In}

plant material is present throughout the unit. The sands are fine to medium grained, subangular to angular, and poorly sorted. The basal contact is sharp and irregular. The irregularities or depressions at the top of the underlying unit are shallow and are filled with as much as 2 in of a clay marl. Included in the basal clay marl are wood fragments, phosphate pebbles, and cobble-sized clay clasts. Overlying the marl is a layer of sandstone blocks that measure 6 in to $3 \mathrm{ft}$ in diameter; the sandstone blocks are occasionally in point contact with the underlying unit. The long dimensions of the sandstone blocks are generally oriented horizontally, but some are oriented at low angles and are imbricate. The blocks are bored on all sides and are encrusted with mollusks, barnacles, and worm tubes. Lithologically, the sandstone is medium to coarse grained, subrounded to subangular, poorly sorted, fossiliferous, quartz sand in a silty matrix; rare granule-sized quartz grains are present, and glauconite occurs in trace amounts. Pieces of wood, bone fragments, and clay clasts as much as $0.75 \mathrm{in}$. in diameter occur sporadically in the blocks. Silty, clay-lined, circular burrows as much as 1 in. in diameter ramify the sandstone. Small (as much as 0.25 in. in diameter), branching, lined burrows are present but rare in the sandstone. Above the zone of sandstone blocks, beds dominated by large mollusks alternate with beds of small mollusks or coral beds to the top of the exposure.

Walkers Bluff, downstream section

Unit 1

Sand and laminated clay. The sands are gray to greenish gray but are commonly iron-stained to yellow orange; the clays are carbonaceous, medium to dark gray. The sands are quartzose and contain minor amounts of mica and glauconite; they are very fine to fine grained, subangular, and well sorted. Finely comminuted plant material is disseminated throughout the unit. Sand is dominant
Unit 2

Thickness

Ft In

over clay throughout the unit and is more abundant in the uppermost $3 \mathrm{ft}$ than it is in the lower part of the unit. Amber, phosphatized pebbles, and fossils (occurring only as impressions) are present in the uppermost $3 \mathrm{ft}$. Discontinuous lenses or pockets of sandstone are present at the top of the unit. The sandstones are gray and consist of fossiliferous medium- to coarse-grained quartz, sparingly glauconitic; scattered phosphate grains are also present.

Sand, $\tan$ to yellow-brown. The sand is dominantly quartzose but contains minor amounts of mica, glauconite, and angular to subangular feldspar clasts. The sand is medium grained, subangular, and poorly sorted. The entire unit is crossbedded, and thin gray clay laminae occur both as drapes along bedding planes and as more or less continuous horizontal laminae that separate sets of crossbeds. Fossils are present as impressions within the clays. The basal contact is sharp and planar; the basal 6 in contains clay clasts, wood fragments, coarsegrained sand, and rare pebbles.

Unit 3 quartzose and has small amounts of glauconite and clay; both glauconite and clay become abundant toward the base of the unit. Blebs of reddish sandy clay are present throughout the unit. The sand is fine to medium grained and subangular. Sorting is variable; some intervals are well sorted, and others, poorly sorted. The unit is unfossiliferous and appears to be massively bedded, although planar bedding is suggested by the presence of a few carbonaceous streaks. A 2-ft-thick, laminated, light-gray clay bed is present $10 \mathrm{ft}$ from the top of the section. The basal contact of the unit cannot be accurately located due to the deep weathering of the sands of units 2 and 3; we considered the contact as occurring at the base of a 4-in-thick clay bed at which a change in slope of the outcrop face takes place. 
Thickness Ft In

Unit 1

Interfingering and alternating sands and clays. The sand beds are yellow brown and commonly are iron stained; the clays are carbonaceous, medium to dark gray. The sands are quartzose and contain minor amounts of glauconite and mica; the clays are silty, laminated, and often contain very fine grained micaceous sand partings. Comminuted plant material occurs both as concentrations along bedding planes and as disseminated particles throughout the unit. The sands are medium grained, subangular, and poorly sorted. No megafossils are present, but pieces of wood occur in both the sands and clays. Ophiomorpha burrows are present in the sands. The sands are crossbedded; large-scale crossbed sets as much as $2 \mathrm{ft}$ thick and thin (3-inthick) clay lenses and drapes dominate the lower $6 \mathrm{ft}$, and clay beds as much as $2.5 \mathrm{ft}$ thick dominate the upper $6 \mathrm{ft}$.

\section{Unit 2}

Sand, yellow-orange. The sands are quartzose, angular to subangular, poorly sorted, and coarse grained. The unit is massive to crossbedded. The basal contact is sharp, and the unit has concentrations of pebbles and cobbles at the base.

\section{Donoho Creek Landing}

Unit 1

Laminated sands and clays; sands and clays present in approximately equal proportions. The sands are gray to greenish gray; the carbonaceous clays are dark gray. The sands are quartzose and contain minor amounts of mica. Comminuted plant material is disseminated throughout the unit. The sands are fine to medium grained, angular to subangular, and poorly sorted; clay-dominated facies contain very fine grained sand partings. A 1-ft-thick, glauconitic, massive, medium- to coarse-grained sand is present at water's edge; the sand contains clay clasts that are piped down in burrows from the overlying clay laminae. Pieces of wood are scattered throughout the unit, but no megafossils were observed.
12

0

Unit 2

Sand, buff to brownish. The sand is quartzose and has minor amounts of mica; the sand is medium to coarse grained, subangular to subrounded, and poorly sorted. The unit is richly fossiliferous; the fossils occur primarily as small, fragmented shell material that is oriented convexly up. Bedding is inclined in part. The basal contact is sharp and irregular; clay clasts at the base have apparently been reworked from the underlying unit.

Unit 3

Sandstone. Weathered surfaces are buff to yellow brown, whereas fresh surfaces are blue gray. The sandstone is quartzose; glauconite is present but rare, and phosphate pebbles as much as $2 \mathrm{~mm}$ in diameter occur throughout the unit. The sand is medium to coarse grained, subrounded to subangular, and poorly sorted. Wood fragments are present throughout the sandstone but are more common toward the base. The unit is richly fossiliferous, and zones of whole larger shells alternate with zones of smaller shells and fragmented shell hash. The sandstone is lenticular, thinning both upstream and downstream, and is contained entirely within the upper half of unit 2; both its upper and its lower contacts are sharp. The unit is crossbedded at the base and grades upward to near-horizontal bedding at the top.

Unit 4

Clay, carbonaceous and dark gray. Very fine grained micaceous sand partings occur throughout the clay. No megafossils are present. The clay is horizontally bedded and is sandy at its base. The basal contact is sharp and planar.

Unit 5

Sand, gray. The sand is primarily quartzose and contains concentrations of quartz pebbles as much as 0.5 in. in diameter, phosphate pebbles, and rare pieces of amber. The phosphate pebbles are rounded and commonly bored by bivalves; one pebble is a worn coprolite.
Thickness

Ft In

56

1

6

2

6

$\begin{array}{ll}0 & 2\end{array}$ 


\begin{abstract}
Also present within the unit are tabular sandstone clasts as much as several inches in length that contain molds of mollusks and one large clast $(8$ in $\times 10$ in $\times 2$ in) that is lithically and faunally like the sandstone of unit 3 . The quartz sands are medium to very coarse grained, subrounded, and poorly sorted. Shells (especially ostreids and clams), vertebrate remains, and shark teeth are common. The basal contact is sharp and planar.

Sandstone, gray. The sand is quartzose in a silty matrix, medium to coarse grained, subangular, and poorly sorted. The sandstone is fossiliferous but contains only Anomia argentaria; it is highly bioturbated, massively bedded, and poorly cemented. The basal contact is sharp and planar.
\end{abstract}

Unit 7 Unit 6

Sand. Weathered surfaces are gray; fresh surfaces are greenish gray. The sands are quartzose and contain minor amounts of mica and glauconite. The unit is a medium-grained sand in a silty matrix; grains are subangular, and the unit is poorly sorted. Shells are abundant, and vertebrate remains are present but rare. The unit is highly bioturbated and massively bedded. The basal contact is gradational over a vertical distance of a few inches.

Unit 8

Sand, $\tan$ to yellow orange. The sand is quartzose, medium to coarse grained, subangular, and well sorted. The unit is unfossiliferous. The entire unit is crossbedded, and its basal contact is sharp and planar. The basal $4 \mathrm{ft}$ consists of very coarse grained sands and gravels.

\section{Robinsons Landing}

Unit 1

Laminated sands and carbonaceous clays; sands and clays present in approximately equal proportions. The sands are gray to greenish gray, and the clays are dark gray. The sands are quartzose and contain minor amounts of mica; comminuted plant material is present throughout the unit. The sands are fine
Thickness

Ft In

10

18

10

0

12

0

to medium grained, subangular, and poorly to well sorted. Very fine grained micaceous sand partings occur within the clay laminae. No megafossils were observed, but wood fragments are scattered throughout the unit.

Unit 2

Sand, dark gray. The sand is quartzose and contains minor amounts of mica, traces of glauconite, fine to mediumgrained phosphate grains, and rare phosphate pebbles, all in a matrix of silt. The sand is medium to coarse grained, subangular to subrounded, and poorly sorted. The unit is fossiliferous; fossils occur as both well-preserved and worn shell material. The basal contact is sharp and planar.

Unit 3

Sand, gray to greenish-gray. The sand is quartzose and contains minor amounts of mica and glauconite. The quartz grains are medium grained to granular, subangular, and poorly sorted and are incorporated in a silty matrix. The unit is fossiliferous, highly bioturbated, and massively bedded. The basal contact is gradational over a few inches.

Unit 4

Shell and shell marl, buff to tan. The shell and marl occur in a medium- to coarse-grained quartz-sand matrix. Phosphate pebbles and nodules are present and commonly are bored. Both whole and fragmented shells are present. The unit occurs as lenticular, discontinuous pockets along the face of the bluff; the basal contact is sharp and irregular.

Unit 5

Sand, yellow-orange. The sand is quartzose, medium to coarse grained, subangular, and well sorted. The unit is unfossiliferous and crossbedded. The basal contact is sharp and undulating; very coarse grained sand and gravel are present in the basal $3 \mathrm{ft}$ of the unit.

\section{Browns Landing}

Unit 1

Sandstone, gray. The sand is quartzose and contains a minor amount of glauco-
Thickness

Ft In 
nite and rare mica. The quartz is medium to coarse grained and subrounded to subangular. The sandstone is fossiliferous, containing both whole and fragmented shells of invertebrates throughout and concentrations of large pieces of wood and worn bone and teeth near the base. Float blocks show the lower part of the sandstone to have inclined bedding that grades to more planar bedding above.

\section{Unit 2}

Sand, buff. The sand is quartzose, medium to coarse grained, and contains an abundance of fine shell hash. In the upper 1 in of the unit, vertebrate remains and granule to pebble-sized phosphate nodules are common. The base of the unit appears to be irregular, filling depressions in the underlying unit.

\section{Unit 3}

Sandstone, gray to brownish-gray. The sand is quartzose in a clayey silt matrix; it contains rare mica and scattered granule-sized, well-rounded phosphate grains. The quartz sand is poorly sorted, fine grained to granule sized, and primarily subangular. The sandstone is fossiliferous; invertebrates are abundant. The upper contact of the unit is covered.

\section{REFERENCES}

Blackwelder, B. W., 1979 [1980], Stratigraphic revision of lower Pleistocene marine deposits of North and South Carolina, in Sohl, N. F., and Wright, W. B., Changes in stratigraphic nomenclature by the U.S. Geological Survey, 1978: U.S. Geological Survey Bulletin 1482-A, p. A52-A61.

Brett, C. E., and Wheeler, W. H., 1961, A biostratigraphic evaluation of the Snow Hill member, Upper Cretaceous of North Carolina: Southeastern Geology, v. 3, no. 2, p. 49-132.

Brouwers, E. M., and Hazel, J. E., 1978, Ostracoda and correlation of the Severn Formation (Navarroan; Maestrichtian) of Maryland: Society of Economic Paleontologists and Mineralogists, Paleontological Monograph 1, $52 \mathrm{p}$.

Christopher, R. A., Owens, J. P., and Sohl, N. F., 1979, Late Cretace- ous palynomorphs from the Cape Fear Formation of North Carolina: Southeastern Geology, v. 20, no. 3, p. 145-159.

Heron, S. D., and Wheeler, W. H., 1964, The Cretaceous formations along the Cape Fear River, North Carolina; Guidebook, 5th Annual Field Excursion, Atlantic Coastal Plain Geological Association, October 9-10, 1964: [Durham, N.C., Duke University] $53 \mathrm{p}$.

Owens, J. P., and Sohl, N. F., 1969, Shelf and deltaic paleoenvironments in the Cretaceous-Tertiary formations of the New Jersey Coastal Plain, in Subitzky, Seymour, ed., Geology of selected areas in New Jersey and eastern Pennsylvania and guidebooks of excursions: New Brunswick, N.J., Rutgers University Press, p. 235-278.

Powers, M. C., 1951, Black Creek deposits along the Cape Fear River, North Carolina: Chapel Hill, University of North Carolina, M.S. thesis.

Sohl, N. F., and Mello, J. F., 1970, Biostratigraphic analysis, in Owens, J. P., Sohl, N. F., and Mello, J. F., Stratigraphy of the outcropping post-Magothy Upper Cretaceous formations in southern New Jersey and northern Delmarva Peninsula, Delaware and Maryland: U.S. Geological Survey Professional Paper 674, p. 28-55.

Sohl, N. F., and Smith, C. C., 1980, Notes on Cretaceous biostratigraphy, in Frey, R. W., ed., Excursions in southeastern geology, v. 2 [Guidebook]-Geological Society of America 1980 Annual Meeting, Atlanta, Georgia: Falls Church, Va., American Geological Institute, p. 392-402.

Stephenson, L. W., 1912, The Cretaceous formations, in Clarke, W. B., and others, The Coastal Plain of North Carolina; Part I, The physiography and geology of the Coastal Plain of North Carolina: North Carolina Geological Survey [Report], v. 3, p. 73-171. -1914 , Cretaceous deposits of the eastern Gulf region and Species of Exogyra from the eastern Gulf region and the Carolinas: U.S. Geological Survey Professional Paper 81, 77 p.

__ 1923, The Cretaceous formations of North Carolina; part I, Invertebrate fossils of the Upper Cretaceous formations: North Carolina Geological Survey [Report], v. 5, 604 p.

-_-1929, Unconformities in Upper Cretaceous Series of Texas: American Association of Petroleum Geologists Bulletin, v. 13, no. 10, p. 1323-1334.

Swift, D. J. P., 1964, Origin of the Cretaceous Peedee Formation of the Carolina Coastal Plain: Chapel Hill, University of North Carolina, Ph.D. dissertation, 163 p.

Swift, D. J. P., and Heron, S. D., Jr., 1967, Tidal deposits in the Cretaceous of the Carolina Coastal Plain: Sedimentary Geology, v. 1, no. 3, p. 259-282.

-_ 1969, Stratigraphy of the Carolina Cretaceous: Southeastern Geology, v. 10, no. 4, p. 201-245.

Swift, D. J. P., Heron, S. D., Jr., and Dill, C. E., Jr., 1969, The Carolina Cretaceous-Petrographic reconnaissance of a graded shelf: Journal of Sedimentary Petrology, v. 39, no. 1, p. 18-33.

Wolfe, J. A., 1976, Stratigraphic distribution of some pollen types from the Campanian and lower Maestrichtian rocks (Upper Cretaceous) of the Middle Atlantic States: U.S. Geological Survey Professional Paper 977, 18 . 

